\title{
Removal of organic magnesium in coccolithophore calcite
}

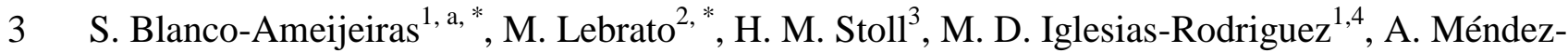

6 (1) National Oceanography Centre, Southampton. University of Southampton, European Way, Southampton, SO14

7 3ZH, United Kingdom.

8 (2) Helmholtz Centre for Ocean Research Kiel (GEOMAR). Düsternbrooker Weg 20, 24105, Kiel, Germany.

9 (3) Department of Geology, University of Oviedo, Arias de Velasco s/n, 33005 Oviedo, Spain.

10 (4) Institute for Life Sciences, University of Southampton, Southampton SO17 1BJ, United Kingdom.

11 (5) Institute for Marine and Antarctic Studies, Private Bag 129, Hobart, TAS 7001, Australia.

13 (a) Present address: Centre of Climate, Meteorology and Global Change (CMMG); University of Azores, Rua Capitão 14 d'Ávila, São Pedro PT 9700-042 Angra do Heroísmo, Açores, Portugal.

16 Correspondence to: S. Blanco-Ameijeiras (sbameijeiras@uac.pt)

$18 *$ : Both authors contributed equally to this work. 
27 Abstract

28 Coccolithophore calcite refers to the plates of calcium carbonate $\left(\mathrm{CaCO}_{3}\right)$ produced by the

29 calcifying phytoplankton, coccolithophores. The empirical study of the elemental composition has a

30 great potential in the development of paleoproxies. However, the difficulties to separate

31 coccolithophore carbonates from organic phases hamper the investigation of coccoliths magnesium

32 to calcium ratios $(\mathrm{Mg} / \mathrm{Ca})$ in biogeochemical studies. Magnesium $(\mathrm{Mg})$ is found in organic

33 molecules in the cells at concentrations up to 400 times higher than in inorganically precipitated

34 calcite in present-day seawater. The aim of this study was to optimize a reliable procedure for

35 organic $\mathrm{Mg}$ removal from coccolithophore samples to ensure reproducibility in measurements of

36 inorganic $\mathrm{Mg}$ in calcite. Two baseline methods comprising organic matter oxidations with (1)

37 bleach and (2) hydrogen peroxide $\left(\mathrm{H}_{2} \mathrm{O}_{2}\right)$ were tested on synthetic pellets, prepared by mixing

38 reagent grade $\mathrm{CaCO}_{3}$ with organic matter from the non-calcifying marine algae Chlorella

39 autotrophica and measured with an ICP-AES (inductively coupled plasma-atomic emission

40 spectrometer). Our results show that treatments with a reductive solution [using hydroxylamine-

41 hydrochloride $\left.\left(\mathrm{NH}_{2} \mathrm{OH} \cdot \mathrm{HCl}+\mathrm{NH}_{4} \mathrm{OH}\right)\right]$ followed by three consecutive oxidations (using $\mathrm{H}_{2} \mathrm{O}_{2}$ )

42 yielded the best cleaning efficiencies, removing > 99\% of organic $\mathrm{Mg}$ in $24 \mathrm{~h} . \mathrm{P} / \mathrm{Ca}$ and $\mathrm{Fe} / \mathrm{Ca}$ were

43 used as indicators for organic contamination in the treated material. The optimized protocol was

44 tested in dried coccolithophore pellets from batch cultures of Emiliania huxleyi, Calcidiscus

45 leptoporus and Gephyrocapsa oceanica. $\mathrm{Mg} / \mathrm{Ca}$ of treated coccolithophores were $0.151 \pm 0.018$,

$460.220 \pm 0.040$, and $0.064 \pm 0.023 \mathrm{mmol} / \mathrm{mol}$, respectively. Comparison with $\mathrm{Mg} / \mathrm{Ca}$ literature

47 coccolith values, suggests a tight dependence on modern seawater $\mathrm{Mg} / \mathrm{Ca}$, which changes as a

48 consequence of different seawater origins $(<10 \%)$. The reliable determination of $\mathrm{Mg} / \mathrm{Ca}$ and $\mathrm{Sr} / \mathrm{Ca}$,

49 and the low levels of organic contamination (Fe/Ca and $\mathrm{P} / \mathrm{Ca}$ ) make this protocol applicable to field

50 and laboratory studies of trace elemental composition in coccolithophore calcite. 
Coccolithophores are marine calcifying phytoplanktonic organisms that play a pivotal role by

54 contributing to the particulate matter production and export via the biological carbon pump

55 (Francois et al., 2002; Gehlen et al., 2007; Ridgwell et al., 2009). The export of inorganic carbon

56 takes place in the form of coccoliths, which are composed of calcium carbonate $\left(\mathrm{CaCO}_{3}\right)$, with

57 minor proportions of magnesium carbonate $\left(\mathrm{MgCO}_{3}\right)$ and strontium carbonate $\left(\mathrm{SrCO}_{3}\right)$ in bloom-

58 forming species such as Emiliania huxleyi and Gephyrocapsa oceanica (Siesser, 1977; Stoll et al.,

59 2001; Stoll et al. 2007; Ra et al., 2010; Müller et al., 2011). Mass accumulation of coccolithophore

60 carbonates has been taking place since coccolithophores first appeared in the sediment record of the

61 Permian/Triassic (P/T) boundary, ca. 250 million years ago (Bown et al., 2004; de Vargas et al.,

62 2004). Sedimentation of inorganic material that has not been dissolved during sinking and

63 accumulated on the seabed (Feely et al., 2004; Berelson et al., 2007) has thus formed an extensive

64 stratigraphical fossil record that is available for geochemical analysis in paleoceanographic studies.

65 The rate of trace elements incorporation (e.g. $\mathrm{Mg}, \mathrm{Sr}$ and $\mathrm{Ba}$ ) in coccolithophore calcite

66 depends largely on their concentration in seawater (Langer et al., 2006a; Ries, 2009; Langer et al.,

67 2009a), but it also follows thermodynamic, kinetic (Morse and Bender, 1990), and biological

68 discrimination imposed by the organisms (Stoll and Schrag, 2000), modulating calcite composition.

69 Experimental data (Stoll et al., 2001; Ra et al., 2010) suggest that temperature might also exert a

70 control on the $\mathrm{Mg} / \mathrm{Ca}$ as in abiogenic calcites (Mucci and Morse, 1987; Tesoriero and Pankow,

71 1996), foraminifera (Barker et al., 2005) and echinoderms (Kroh and Nebelsick, 2010). Mg/Ca has,

72 therefore, been used as a paleothermometry proxy, although "cleaning issues" in removing organic

$73 \mathrm{Mg}$ have precluded a widespread implementation in coccolithophore carbonates (Stoll et al., 2001;

74 Stoll and Ziveri, 2004; Ra et al., 2010; Müller et al., 2011). An understanding of the Mg 
75 contribution and composition in sinking carbonates also allows assessing susceptibilities to

76 dissolution [e.g. the biomineral saturation state with respect to $\mathrm{Mg}$ phases (Andersson et al., 2008)].

77 However, this is more relevant in high magnesium (> $4 \% \mathrm{MgCO}_{3}$ ) carbonates (e.g. Morse et al.,

78 2006; Kuffner et al., 2007).

79 Magnesium is abundant in the organic fraction of coccolithophores. This element is present in

80 biomolecules, such as chlorophyll, where it is a central ion in the porphyrin ring (e.g. $\mathrm{Mg}$ -

81 protoporphyrin and Mg -2, 4-diviniyl pheoporphyrin a) (Stanier and Smith, 1959; Chereskin et al.,

82 1982). Magnesium also binds to cellular polyphosphate compounds such as RNA and DNA (Lusk

83 et al., 1968), and adenosine triphosphate (ATP), which is the main energetic molecule for cellular

84 metabolism (Leroy, 1926). Furthermore, magnesium acts as a co-factor to activate multiple cell

85 enzymes (Legong et al., 2001). Therefore, studies based on the $\mathrm{Mg} / \mathrm{Ca}$ in biogenic calcite (e.g.

86 laboratory incubations, sediment traps, and sediment cores) require removal of $\mathrm{Mg}$ associated to

87 organic phases in order to prevent contamination of the inorganic phases (Stoll et al., 2001; Barker

88 et al., 2003). The major present limitations in cleaning procedures are the small size of the

89 individual coccoliths that complicate individual manipulation, and the low $\mathrm{Mg}$ content in calcite (<

$900.1 \mathrm{mmol} / \mathrm{mol}$ ) (Stoll et al., 2001, Stoll et al., 2007; Ra et al., 2010).

91 In this study we optimized cleaning methods using synthetic samples of non calcite-bearing

92 marine organic matter and abiogenic reagent calcite whose $\mathrm{Mg} / \mathrm{Ca}$ was independently measured.

93 The effectiveness of the cleaning protocols and uncertainties can therefore be assessed. The

94 optimization procedure focused on two baseline methods consisting in organic matter oxidations

95 with (1) bleach, and (2) hydrogen peroxide. The protocol G, which yielded the highest cleaning

96 efficiency with respect to reagent grade $\mathrm{CaCO}_{3}(>99 \%)$ and the lowest $\mathrm{P}$ and $\mathrm{Fe}$ contamination

97 levels, requiring less time of incubation $(\sim 24 \mathrm{~h})$, was applied to dry pellets of three widespread

98 coccolithophore species (Emiliania huxleyi, Gephyrocapsa oceanica, and Calcidiscus leptoporus). 
99 Calcite elemental ratios ( $\mathrm{Mg} / \mathrm{Ca}$ and $\mathrm{Sr} / \mathrm{Ca}$ ), organic phases and Fe oxides (Tang and Morel, 2006)

100 contamination indicators $(\mathrm{P} / \mathrm{Ca}$ and $\mathrm{Fe} / \mathrm{Ca})$ of synthetic and coccolithophore pellets, were

101 determined via inductively coupled plasma-atomic emission spectrometry (ICP-AES). Additionally,

102 we report the culture media conditions (abiotic factors, seawater carbonate chemistry and $\mathrm{Mg} / \mathrm{Ca}$

103 ratios) as well as physiological parameters: particulate carbon production and organic $\mathrm{C} / \mathrm{N}$. The

104 protocol optimized and tested here considerably reduces the uncertainties in the study of $\mathrm{Mg} / \mathrm{Ca}$ in

105 coccolithophore calcite and monitors organic matter contamination through $\mathrm{P} / \mathrm{Ca}$ and $\mathrm{Fe} / \mathrm{Ca}$. This

106 will allow expanding the use of $\mathrm{Mg} / \mathrm{Ca}$ as a proxy and also to measure/calibrate data from

107 laboratory experiments to assess responses of coccolith chemistry to different environmental

108 conditions.

109

110

111

112

113

114

115

116

117

118

119

120

121

122 


\section{METHODS}

\section{2.1. Culture methods}

126

127 Monoclonal cultures of two species of coccolithophore Emiliania huxleyi CAWPO6 and

128 Calcidiscus leptoporus RCC1169 and a green alga Chlorella autotrophica CCMP243 were grown

129 at the National Oceanography Center, Southampton (United Kingdom). Cultures were incubated at

$13019.3 \pm 0.8^{\circ} \mathrm{C}$ in a light:dark cycle of $12: 12$ hours. The photosynthetically active radiation (PAR) was

$131125 \pm 10 \mu \mathrm{mol}$ quanta $\mathrm{m}^{-2} \mathrm{~s}^{-1}$, provided by cool-white fluorescent lamps (Osram LUMILUX), and

132 salinity was $35 \pm 1$ (culture conditions are summarized in Table 1). The culture medium was

133 prepared using filter-sterilized $(0.22 \mu \mathrm{m})$ seawater from the Celtic Sea, offshore Plymouth (UK),

134 and enriched with $100 \mu \mathrm{M}$ sodium nitrate $\left(\mathrm{NaNO}_{3}\right)$ and $6.4 \mu \mathrm{M}$ sodium di-hydrogen phosphate

$135\left(\mathrm{NaH}_{2} \mathrm{PO}_{4}\right)$, and trace metals and vitamins were added following the $\mathrm{f} / 2$ medium recipe (Guillard

136 and Ryther, 1962; Guillard, 1975).

137 Chlorella autotrophica was grown in triplicate using $12 \mathrm{~L}$ of culture medium in sterilized 20

138 L polycarbonate culture vessels under similar environmental conditions as the coccolithophores

139 (Table 1). Emiliania huxleyi and C. leptoporus were cultured in duplicate, using 3 L of culture

140 medium, in sterile $5 \mathrm{~L}$ borosilicate Erlenmeyer flasks. The carbonate chemistry system of the

141 medium reflected the original coastal water at present-day conditions $\left(\mathrm{pH}_{\text {total }}=7.82\right.$ and 7.94,

142 respectively), and it was left equilibrating with the atmosphere in the chambers (see Table 1 for

143 initial and final values). At the start of all experiments the carbonate chemistry of the medium was

144 in the range of present-day observations (Key et al., 2004), but at the time of harvest (as a

145 consequence of high biomass) C. leptoporus had consumed $28.3 \%$ of the dissolved inorganic

146 carbon (DIC). Particulate organic and inorganic carbon measurements (cell quota and production 
147 rates $)$ were in agreement $\left(\mathrm{PIC}_{\mathrm{POC}} \mathrm{P}\right.$. huxleyi $=0.81, \mathrm{PIC}_{\mathrm{POC}}$. leptoporus $\left.=2.18\right)$ with published data

148 sets at present-day carbonate chemistry conditions (e.g. Langer et al., 2006b; Iglesias-Rodriguez et

149 al., 2008) (see Table 1). Gephyrocapsa oceanica (RCC1303) was cultured at the Helmholtz Centre

150 for Ocean Research Kiel (GEOMAR, Germany) in a climate chamber at $20{ }^{\circ} \mathrm{C}$ (Table 1) with a $16: 8$

151 hours light:dark cycle using a PAR of $150 \mu \mathrm{mol}$ quanta $\mathrm{m}^{-2} \mathrm{~s}^{-1}$. Cultures were grown in individual

152 2.5 L polycarbonate bottles (closed system) in artificial seawater (Kester et al., 1967) enriched with

$15364 \mu \mathrm{M}$ of $\mathrm{NaNO}_{3}$ and $4 \mu \mathrm{M}$ of $\mathrm{NaH}_{2} \mathrm{PO}_{4} \cdot \mathrm{H}_{2} \mathrm{O}$ and trace metals and vitamins according to $\mathrm{f} / 8$

154 medium recipe (Guillard and Ryther, 1962; Guillard, 1975). Carbonate chemistry was adjusted to

155 present-day conditions $\left(\mathrm{pH}_{\text {total }}=8.03\right)$ by combined additions of $\mathrm{Na}_{2} \mathrm{CO}_{3}$ and $\mathrm{HCl}$ as described in

156 the EPOCA Guide to best practices in ocean acidification research and data reporting (Gattuso et

157 al., 2010). Parameters of the carbonate chemistry system and determination for each culture are

158 summarized in Table 1. All experimental cultures (for the three species) were inoculated from

159 cultures pre-acclimated to experimental conditions for at least eight generations, in exponential

160 growth phase.

161

\section{2.2. Pellet preparation}

163

164 2.2.1. Synthetic pellets

165

166 Synthetic pellets were prepared by mixing $5 \mathrm{~mL}$ of a suspension of $10 \mathrm{~g} \mathrm{~L}^{-1}$ of reagent grade

$167 \mathrm{CaCO}_{3}$ powder, with $5 \mathrm{~mL}$ of a suspension of the non-calcifying marine microalgae Chlorella

168 autotrophica $\left(\sim 1.5 \times 10^{6}\right.$ cell $\left.\mathrm{mL}^{-1}\right)($ Electronic annex EA-1). The mixture was centrifuged with a

169 relative centrifuge force (RCF) of $1970 \mathrm{~g}$ for 20 minutes at $4{ }^{\circ} \mathrm{C}$ in a Hettich ROTANTA 460RS

170 Centrifuge. After discarding the supernatant, the synthetic pellets were frozen at $-80^{\circ} \mathrm{C}$, freeze- 
171 dried for $48 \mathrm{~h}$ in Falcon tubes (Harris, 1954), and kept at room temperature until analysis.

172 Additionally, control samples were prepared with a suspension of $10 \mathrm{~g} \mathrm{~L}^{-1}$ of reagent-grade $\mathrm{CaCO}_{3}$

173 (without algal addition) following the same protocol as for the preparation of synthetic pellets (EA-

174 1). The pellets were produced in a single batch, with similar weights and $\mathrm{CaCO}_{3}$ /organic matter

175 ratios (EA-1), then freeze-dried for $48 \mathrm{~h}$, and stored at room temperature for two weeks before

176 analysis. Thus, differences among the individual pellets as well as the bacterial oxidation effect

177 (Stoll et al., 2001) were minimized to assess the net organic Mg removal achieved purely by

178 chemical treatment (protocol). Stoll et al. (2001) reported that synthetic pellets of untreated $C$.

179 autotrophica $+\mathrm{CaCO}_{3}$ had similar $\mathrm{Mg} / \mathrm{Ca}$ as those from samples extracted from coccolithophore

180 cultures with high organic content $(0.5-300 \mathrm{mmol} / \mathrm{mol})$. Therefore, we assumed that our synthetic

181 pellets also reproduced well the properties of coccolithophore material to test the organic $\mathrm{Mg}$

182 removal protocols.

183

184 2.2.2. Coccolithophore pellets

185

186 Cultures of coccolithophores were concentrated into cellular pellets (one pellet per replicate

187 bottle) by centrifugation. Since the culture experiments were conducted at different laboratories, the

188 facilities available conditioned the application of two different procedures of centrifugation (Fig. 1).

189 A Hettich ROTANTA 460RS Centrifuge was used at the National Oceanography Centre

190 Southampton (it only fits conic-bottom tubes), and a Beckman AVANTI ${ }^{\mathrm{TM}}$ J-25 Centrifuge was

191 used at the GEOMAR (it fits only flat-bottom tubes). The two separation techniques used to harvest

192 coccolithophore pellets were as follows (Fig. 1): (1) Gephyrocapsa oceanica was centrifuged in

193 flat-bottom tubes, where the calcite forms a characteristic rim around the organic matter (free

194 coccoliths), and (2) Emiliania huxleyi and Calcidiscus leptoporus were centrifuged in conical- 
195 bottom tubes, where all the material was mixed. In the first procedure, calcite was selected by

196 pipetting from the rim around the organic matter, which allows performing several initial manual

197 discrimination of organic matter. In the second one, this was not possible and all material remained

198 mixed until cleaning protocols were applied (Fig 1). Therefore a former method would be preferred.

\section{2.3. Cleaning protocols}

201

202 Two different oxidation procedures were applied during the protocol optimization. The first

203 one was a bleach-based method consisting of consecutive oxidations with a solution of sodium

204 hypochlorite $(10 \% \mathrm{NaClO} v / \mathrm{v})$ for $24 \mathrm{~h}$ at room temperature (Table 2$)$. The second one involved an

205 oxidizing solution of alkaline hydrogen peroxide [0.33\% (v/v) $\mathrm{H}_{2} \mathrm{O}_{2}+0.98 \%(\mathrm{v} / \mathrm{v}) \mathrm{NaOH}$, based

206 on a method originally developed by Boyle (1983) and widely used to clean $\mathrm{Mg} / \mathrm{Ca}$ samples in

207 foraminifera (Martin and Lea, 2002; Barker et al., 2003; Barker et al., 2005). In foraminifera

208 samples rich in organic phases from cultures (Russell et al., 2004) and sediment traps (Anand et al.,

209 2003; Pak et al., 2004), the oxidizing solution was applied in higher concentrations for longer time

210 periods. In the present study, the oxidative incubations started with pellet immersion in the alkaline

$211 \mathrm{H}_{2} \mathrm{O}_{2}$ solution (inside $15 \mathrm{~mL}$ tubes) during 10-15 min (Table 2) in an ultrasonic bath at room

212 temperature, which disrupts organic matter and enhances oxidation power. Afterwards, the

213 temperature was raised to $\sim 100{ }^{\circ} \mathrm{C}$ in a water-bath, to break down the residual $\mathrm{H}_{2} \mathrm{O}_{2}$, removing it

214 from the solution. Any associated impurities were brought into suspension, and then removed in

215 subsequent rinses with ultra pure water (UP-water) (Table 2). Several variations were introduced in

216 the original protocol to achieve the most effective and rapid treatment (Table 2): (1) Rinses with

217 UP-water and manual removal of organic matter by pipetting before the oxidative incubations

218 (treatments F-H), (2) reductive incubation using a solution of $4.76 \%(\mathrm{v} / \mathrm{v}) \mathrm{NH}_{2} \mathrm{OH} \cdot \mathrm{HCl}+38 \%(\mathrm{v} / \mathrm{v})$ 
$219 \mathrm{NH}_{4} \mathrm{OH}$ (Boyle, 1981) before oxidation (treatments C, E, G, H), (3) increase in the number of

220 oxidizing incubations (treatment B), and (4) modifications in the volume of reactive solution and

221 UP-water according to sample size. All the reagent solutions used were alkaline to avoid carbonate

222 dissolution. The efficiency in removing organic $\mathrm{Mg}$ phases was assessed by comparison with

223 elemental ratios measured on reagent-grade $\mathrm{CaCO}_{3}$. Phosphorus and iron $(\mathrm{P} / \mathrm{Ca}$ and $\mathrm{Fe} / \mathrm{Ca})$ were

224 used as indicators of contamination by organic matter and Fe-oxyhydroxides, respectively.

225

226 2.4. Measurements of elemental ratios via ICP-AES

227

Treated pellets were transferred to microfuge tubes $(1.5 \mathrm{~mL})$, dissolved in $250 \mu \mathrm{L}$ of ultra-

229 pure $2 \% \mathrm{HNO}_{3}$ and diluted in $750 \mu \mathrm{L}$ of UP-water. Elemental analysis was performed in an ICP-

230 AES, using the Thermo $i$ CAP 6300 Series ICP Spectrometer (installed in the Department of

231 Geology, University of Oviedo, Spain). To improve precision by minimizing matrix effects, all

232 samples were diluted to similar Ca concentrations for final analysis of trace metal/Ca ratios. To this

233 end, an aliquot of $50 \mu \mathrm{L}$ of dissolved material was analyzed for Ca concentration. Based on the

234 measured $\mathrm{Ca}$, the reminder of the samples were diluted to a common Ca level, seeking the highest

235 possible $\mathrm{Ca}$ concentration within the range of standard calibration solutions $(\mathrm{Ca}=15,50,100 \mathrm{ppm})$.

236 For trace elemental ratios, we measured in both radial and axial mode: $\mathrm{P}$ (177 nm axial), Fe (259

$237 \mathrm{~nm}$ radial), $\mathrm{Ca}$ (315 $\mathrm{nm}$ radial) and $\mathrm{Sr}$ (407 nm radial). Calibrations were performed with multi-

238 element standards offline using the intensity ratio method described in de Villiers et al. (2002).

239 Elemental ratios of non-treated coccolithophore samples (only for E. huxleyi and $C$.

240 leptoporus) were obtained as a by-product from the measurements of Ca concentration for

241 determination of particulate inorganic carbon (PIC). These samples were obtained by filtering 200

$242 \mathrm{~mL}$ of culture medium at harvesting time through a $0.22 \mu \mathrm{m}$ Cyclopore polycarbonate membrane 
243 and rinsed with buffered ultra-pure water $(\mathrm{pH} \sim 9)$. Samples were stored at $-20^{\circ} \mathrm{C}$ until analysis.

244 Before analysis the samples were dried for $24 \mathrm{~h}$ at $60^{\circ} \mathrm{C}$, dissolved in ultra-pure $2 \% \mathrm{HNO}_{3}$ and

245 analyzed using the ICP-AES, Thermo $i$ CAP 6300 Series ICP Spectrometer.

$246 \mathrm{Mg} / \mathrm{Ca}$ and $\mathrm{Sr} / \mathrm{Ca}$ in seawater were determined separately by the method of standards addition

247 in culture medium samples $(0.22 \mu \mathrm{m}$ filtered $)$ diluted to $1 / 200$ and $1 / 10$ respectively, and measured

248 with a Thermo $i$ Cap 6300 Series ICP Spectrometer as described above. The partition coefficients of

$249 \mathrm{Mg}\left(\mathrm{D}_{\mathrm{Mg}}\right)$ and $\mathrm{Sr}\left(\mathrm{D}_{\mathrm{Sr}}\right)$ between coccoliths' calcite and seawater were calculated as elemental ratios

250 of coccolithophore calcite divided by the same elemental ratio obtained for the seawater $\left[\mathrm{D}_{x}=\right.$

$251(x / \mathrm{Ca})_{\text {calcite }} /(x / \mathrm{Ca})_{\text {seawater }}$; where $x$ is the trace element of interest $]$.

252

253 2.5. Protocol assessment criteria

254

255

$\mathrm{P} / \mathrm{Ca}$ and $\mathrm{Fe} / \mathrm{Ca}$ were used as indicators of organic contamination and oxyhydroxides coating,

256 respectively (Fig. 3). The P/Ca was selected because phosphorus is an essential component of

257 biomolecules in the cell metabolism such as nucleotides [structural units of DNA and RNA, and

258 energetic molecules like ATP] and phospholipids (essential constituents of cellular membranes)

259 (Chu, 1946). Fe/Ca was selected because iron is generally a major compound in the trace metals

260 stock solution added to culture medium (e.g. Guillard and Ryther, 1962). It can be deposited on the

261 cell surface as Fe-oxides binding organic molecules (Ho et al., 2003; Tang and Morel, 2006), which

262 have high affinity to bind organic ligands (Wu and Luther, 1995; Rue and Bruland, 1997; Barker et

263 al., 2003).

264 The efficiency of the protocols was assessed by comparing different elemental ratios $(\mathrm{Mg} / \mathrm{Ca}$,

$265 \mathrm{Fe} / \mathrm{Ca}$ ) measured in treated synthetic pellets with the same elemental ratios measured in samples of

266 reagent-grade $\mathrm{CaCO}_{3}$ in the same analysis (Fig. 2). In this study, elemental ratios of non-treated 
267 synthetic pellets were not determined. Therefore, removal efficiency of organic Mg cannot be 268 accurately calculated with respect to synthetic pellets $\left(\right.$ Chlorella $\left.+\mathrm{CaCO}_{3}\right)$, but it can be done with 269 respect to the original $\mathrm{CaCO}_{3}$ sample. Since all the synthetic pellets were produced with similar

270 proportions of organic/inorganic material (see EA-1), the relative amount of organic $\mathrm{Mg}$ and $\mathrm{Fe}$

271 removed after the treatment was estimated by comparison with the reagent-grade $\mathrm{CaCO}_{3}$ following 272 the equation $($ Fig. 2$)$ : $\%$ organic contamination removed $=\left[\left(1-\right.\right.$ ratio $\left.\left._{\text {sample }}\right) \times 100\right] /\left(1-\right.$ ratio $_{\text {reagent }}$ $273 \mathrm{CaCO} 3)$

274 For the coccolith samples, subsequently cleaned with the optimized protocol, we cannot

275 calculate the cleaning efficiency since we did not independently determine the trace elemental ratios

276 in the pure coccolithophore calcite. For these samples we estimate the percentage of organic $\mathrm{Mg}$

277 removed during the cleaning treatment comparing with the elemental ratios determined in non278 treated samples (Emiliania huxleyi and Calcidiscus leptoporus) (Table 3).

279

280

281

282

283

284

285

286

287

288

289

290 


\section{RESULTS}

292

\section{3.1. Protocol optimization on synthetic pellets}

294

295 $\mathrm{Mg} / \mathrm{Ca}$ measured in synthetic pellets treated with bleach [treatments A-C (Table 2, Fig. 2)]

296 ranged from 0.335 to $0.545 \mathrm{mmol} / \mathrm{mol}$, which were higher than $0.136 \pm 0.008 \mathrm{mmol} / \mathrm{mol} \mathrm{measured}$

297 in the samples of certified $\mathrm{CaCO}_{3}$ used as a control (EA-2). The estimated percentage of organic

$298 \mathrm{Mg}$ removed was $<80 \%$ in all the bleach-based treatments (A-C) (Fig. 2a). These protocols were

299 effective in removing $\mathrm{P}$ (average $\mathrm{P} / \mathrm{Ca}=0.072 \mathrm{mmol} / \mathrm{mol}$ ) (Fig. 3b). However, Fe/Ca was still high,

$300>2 \mathrm{mmol} / \mathrm{mol}$ (Fig. 3a). The $\mathrm{Sr} / \mathrm{Ca}$ was $0.043 \pm 0.002 \mathrm{mmol} / \mathrm{mol}$ in the bleach-based treatments (A-

$301 \mathrm{C}$ ) and the values measured in the reagent grade $\mathrm{CaCO}_{3}$ samples were $0.042 \pm 0.002 \mathrm{mmol} / \mathrm{mol}$.

302 The introduction of an additional oxidation step in treatment B (Table 2), after four oxidations with

303 bleach ( $24 \mathrm{~h}$ each incubation), did not decrease the $\mathrm{Mg} / \mathrm{Ca}(0.415 \mathrm{mmol} / \mathrm{mol})$, even though the $\mathrm{P} / \mathrm{Ca}$

304 decreased from 0.042 to $0.012 \mathrm{mmol} / \mathrm{mol}$. In treatment $\mathrm{C}$, the introduction of an initial reductive

305 incubation (Table 2) decreased the Fe/Ca from $4.808 \mathrm{mmol} / \mathrm{mol}$ (treatment A) to $0.157 \mathrm{mmol} / \mathrm{mol}$.

306 However, the $\mathrm{Mg} / \mathrm{Ca}$ was similar to previous treatments $(0.429 \mathrm{mmol} / \mathrm{mol})$. Total time of

307 incubation required in the bleach-based treatments was $96 \mathrm{~h}$ for treatment $\mathrm{A}$, and $120 \mathrm{~h}$ for

308 treatments B and C. Treatments D-H were based on oxidations with $\mathrm{H}_{2} \mathrm{O}_{2}$ and were in general more

309 efficient in reducing the $\mathrm{Fe} / \mathrm{Ca}$, although $\mathrm{Mg} / \mathrm{Ca}$ and $\mathrm{P} / \mathrm{Ca}$ did not behave equally (Fig. 3).

310 Treatment $\mathrm{D}$, consisting in four consecutive oxidations with $\mathrm{H}_{2} \mathrm{O}_{2}$, retrieved $0.954 \pm 0.056$

$311 \mathrm{mmol} / \mathrm{mol}$ of $\mathrm{Mg} / \mathrm{Ca}$ and the $\mathrm{P} / \mathrm{Ca}$ was still high $(0.171 \pm 0.043 \mathrm{mmol} / \mathrm{mol})$ in comparison to the

312 values measured in the reagent grade $\mathrm{CaCO}_{3}(0.123 \pm 0.007$ and $0.005 \pm 0.001 \mathrm{mmol} / \mathrm{mol}$,

313 respectively). However, it was more effective in decreasing the $\mathrm{Fe} / \mathrm{Ca}$, requiring only $\sim \mathrm{h}$ of

314 incubation (Fig. 2). Treatment E, which introduced a reductive incubation before the oxidations, 
315 retrieved a lower $\mathrm{Mg} / \mathrm{Ca}(0.230 \pm 0.068 \mathrm{mmol} / \mathrm{mol})$ and $\mathrm{P} / \mathrm{Ca}(0.098 \pm 0.033 \mathrm{mmol} / \mathrm{mol})$. The

316 percentage of $\mathrm{Mg}$ removed rose up to $87.72 \%$ and the $\mathrm{P} / \mathrm{Ca}$ decreased a further $43 \%$. The

317 application of UP-water rinses before the oxidation steps (treatment F) decreases the P/Ca and

$318 \mathrm{Fe} / \mathrm{Ca}$ in $40 \%$ and $66 \%$, in comparison with treatment $\mathrm{E}$, and the $\mathrm{Mg} / \mathrm{Ca}$ decreases to $0.188 \pm 0.021$

$319 \mathrm{mmol} / \mathrm{mol}$. Therefore, a combination of initial UP-water rinses, reductive and oxidative incubations

320 was applied in treatment $\mathrm{G}$ (Table 2) and the $\mathrm{Mg} / \mathrm{Ca}$ decreased to $0.158 \pm 0.0003 \mathrm{mmol} / \mathrm{mol}$ as well

321 as the $\mathrm{P} / \mathrm{Ca}$ and $\mathrm{Fe} / \mathrm{Ca}$ (Fig. 2, 3). Before applying this protocol to the coccolithophore samples,

322 minor adjustments in the number of UP-water rinses, oxidation steps, and volumes used were

323 introduced in treatment $\mathrm{H}$ to prevent carbonate loss during samples cleaning (previously observed

324 in other treatments, with more reactive volume and more UP-water rinses and oxidations). In a short

325 time [24.5 $\mathrm{h}$ of incubation (Table 2)], treatment $\mathrm{H}$ delivered the best results in removing organic $\mathrm{Mg}$

326 (> 99.9\%) and was selected to apply to coccolithophore samples. The measurements of P/Ca and

$327 \mathrm{Fe} / \mathrm{Ca}(0.043$ and $0.029 \mathrm{mmol} / \mathrm{mol}$, respectively) after application of treatment $\mathrm{H}$ were still above

328 measurements in reagent grade $\mathrm{CaCO}_{3}$ samples (0.028 and $0.001 \mathrm{mmol} / \mathrm{mol}$, respectively) (Fig. 2).

329 The large standard deviation registered in the $\mathrm{P} / \mathrm{Ca}$ in synthetic pellets may be attributed to the

330 variability introduced by the cleaning protocol. When samples of reagent grade $\mathrm{CaCO}_{3}$ were treated

331 with the optimized protocol $\mathrm{H}$, the $\mathrm{Mg} / \mathrm{Ca}$ and $\mathrm{Sr} / \mathrm{Ca}$ did not vary from those measured in non-

332 treated $\mathrm{CaCO}_{3}$ (Fig. 4).

333

\section{3.2. Application of the optimized protocol to coccolithophore samples}

The $\mathrm{Mg} / \mathrm{Ca}$ determined in untreated culture samples of Emiliania huxleyi was $48 \pm 4$

$337 \mathrm{mmol} / \mathrm{mol}$ (Table 3). After the implementation of protocol $\mathrm{H}$, the $\mathrm{Mg} / \mathrm{Ca}$ was $0.15 \pm 0.02 \mathrm{mmol} / \mathrm{mol}$

338 (Fig. 4), and for treated Gephyrocapsa oceanica pellets it was $0.06 \pm 0.02 \mathrm{mmol} / \mathrm{mol}$ (Fig. 4). The 
$339 \mathrm{Mg} / \mathrm{Ca}$ determined for treated samples of Calcidiscus leptoporus was $0.22 \pm 0.04 \mathrm{mmol} / \mathrm{mol}$ (Fig.

340 4), while for non-treated samples this ratio was $4.2 \pm 0.4 \mathrm{mmol} / \mathrm{mol}$ (Table 3 ). In samples of $E$.

341 huxleyi the cleaning treatment was estimated to remove $99.7 \%$ of $\mathrm{Mg}, 99.3 \%$ of $\mathrm{P}$, and $98.1 \%$ of $\mathrm{Fe}$

342 associated with organic phases (Table 3). Just a 22.6\% of the $\mathrm{Sr}$ was removed, which indicates that

343 the contribution of organic phases to inorganic Sr was small. In samples of Calcidiscus leptoporus,

344 the estimated removal of $\mathrm{Mg}$ during cleaning was $94.8 \%$, estimated $\mathrm{Sr}$ removal was $6.9 \%$, and

345 estimated phosphorus and iron removal were $93.4 \%$ and $79.6 \%$ respectively. The Fe/Ca determined

346 in E. huxleyi and C. leptoporus $(7.6$ and $5.6 \mathrm{mmol} / \mathrm{mol})$ was much higher than that in G. oceanica

347 (0.001 mmol/mol) (Fig. 4). The P/Ca was overall higher in E. huxleyi and G. oceanica (0.75 and

$3480.79 \mathrm{mmol} / \mathrm{mol}$, respectively) compared to C. leptoporus $(0.40 \mathrm{mmol} / \mathrm{mol})$. Sr/Ca varied among the

349 different species; the lowest ratio was observed in E. huxleyi $(2.73 \pm 0.22 \mathrm{mmol} / \mathrm{mol})$, followed by

350 C. leptoporus $(3.05 \pm 0.010 \mathrm{mmol} / \mathrm{mol})$ and then $G$. oceanica $(3.41 \pm 0.10 \mathrm{mmol} / \mathrm{mol})$. Since we

351 used, artificial (laboratory) and natural seawater (coastal), the medium $\mathrm{Mg} / \mathrm{Ca}$ varied (5.67 mol/mol

352 in E. huxleyi, $5.83 \mathrm{~mol} / \mathrm{mol}$ in C. leptoporus and $5.63 \mathrm{~mol} / \mathrm{mol}$ in G. oceanica cultures at harvesting

353 time). The variation in $\mathrm{Mg} / \mathrm{Ca}$ of coccoliths from different species, all grown at similar temperatures

$354\left(19.8 \pm 0.3^{\circ} \mathrm{C}\right)$, was correlated with the seawater $\mathrm{Mg} / \mathrm{Ca}\left(\mathrm{R}^{2}=0.84 ; F=140.40, \mathrm{P}<0.0001\right)$ (Fig.

355 5). Partition coefficients for $\mathrm{Mg}$ also varied among the different species from $1.1 \times 10^{-5} \pm 0.4 \times 10^{-5}$ in

356 G. oceanica, and $2.7 \times 10^{-5} \pm 0.3 \times 10^{-5}$ in E. huxleyi, to $3.8 \times 10^{-5} \pm 0.7 \times 10^{-5}$ in C. leptoporus. 357

358

359

360

361

362 


\section{DISCUSSION}

\section{4.1. The cleaning protocol}

In this study, bleach-based cleaning treatments removed a very low percentage of organic $\mathrm{Mg}$

368 and took a long incubation time. Therefore, the optimization efforts focused on $\mathrm{H}_{2} \mathrm{O}_{2}$-based

369 treatments. Even though the decrease in Fe/Ca obtained with treatment $\mathrm{C}$ (Table 2) indicated that

370 further optimization tests including initial rinses with UP-water might improve the efficiency in

371 removing organic phases, the experimental matrix of this study was not completed. Pak et al. (2004)

372 also implemented bleach- and $\mathrm{H}_{2} \mathrm{O}_{2}$-based protocols on sediment trap foraminifera material (rich in

373 organic phases). Their results concluded that $\mathrm{Mg} / \mathrm{Ca}$ on samples treated with bleach were

374 consistently higher and reproducibility was significantly lower than the samples treated with $\mathrm{H}_{2} \mathrm{O}_{2}$.

375 Oxidizing reagents are effective in decomposing organic compounds into more hydrophilic groups,

376 which was reflected in the removal of phosphorus (Fig. 2). However, in coccolithophore culture

377 samples, a portion of the iron added to the culture medium (in the trace metals stock solution) forms

378 ferric oxyhydroxides, and oxide $\left(\mathrm{FeO}_{x}\right)$ precipitates, which become associated with cell surfaces,

379 and might adsorb other trace elements interfering with the elemental analysis (Ho et al., 2003; Tang

380 and Morel, 2006). Therefore, a reductive incubation with a solution of hydroxylamine-

381 hydrochloride (Boyle, 1981) was introduced as a previous step before the oxidative incubations to

382 remove organic phases associated with metal oxides. The decrease in the Fe/Ca in coccolithophore

383 samples was large, but a complete removal of iron was not achieved (Fig. 2). The values of Fe/Ca

$384(0.0006 \mathrm{mmol} / \mathrm{mol})$ in pellets of G. oceanica were lower than the Fe/Ca measured in E. huxleyi and

385 C. leptoporus (Fig. 4). This could be attributed to the smaller addition of Fe in the culture medium

$386\left(2.93 \cdot 10^{-3} \mu \mathrm{M}\right.$ of $\mathrm{FeCl}_{3} \cdot 6 \mathrm{H}_{2} \mathrm{O}$ for G. oceanica, compared to $11.7 \cdot 10^{-3} \mu \mathrm{M}$ of $\mathrm{FeCl}_{3} \cdot 6 \mathrm{H}_{2} \mathrm{O}$ added 
387 besides the natural values for E. huxleyi and C. leptoporus) (Boye and van der Berg, 2000; Ho et al.,

388 2003; Tang and Morel, 2006). Results from Bian and Martin (2010) on foraminifera $\mathrm{CaCO}_{3}$

389 samples indicate that the use of reductive treatments may be acceptable for the $\mathrm{Mg} / \mathrm{Ca}$ analysis even

390 though there is a potential risk of sample partial dissolution, lowering the $\mathrm{Mg} / \mathrm{Ca}$ (Barker et al.,

391 2003; Yu et al., 2007). In the present study, $\mathrm{Mg} / \mathrm{Ca}$ measured in treatments $\mathrm{F}$ and $\mathrm{G}$ [essentially

392 identical except in the initial reductive cleaning in $\mathrm{G}$ (see Table 2)] indicated that the

393 hydroxylamine-hydrochloride solution applied decreased the $\mathrm{Mg} / \mathrm{Ca}$ by $0.030 \mathrm{mmol} / \mathrm{mol}$ (Fig. 2,

394 EA-2). Even though, the potential partial dissolution of carbonate phases was not directly assessed

395 (no SEM images available), we suggest that this reduction is associated with removal of organic $\mathrm{Mg}$

396 rather than partial dissolution of the $\mathrm{CaCO}_{3}$ (Barker et al., 2003; Yu et al., 2007; Bian and Martin,

397 2010). This is because the $\mathrm{Mg} / \mathrm{Ca}$ determined in samples of reagent grade $\mathrm{CaCO}_{3}$ treated with the

398 optimized protocol (treatment $\mathrm{H}$ ) was equal to the $\mathrm{Mg} / \mathrm{Ca}$ in non-treated reagent-grade $\mathrm{CaCO}_{3}$

$399(0.149 \mathrm{mmol} / \mathrm{mol}$ in both cases $)$. Identical results were obtained for the $\mathrm{Sr} / \mathrm{Ca}$ determined in treated

400 and non-treated reagent-grade $\mathrm{CaCO}_{3}(0.039 \mathrm{mmol} / \mathrm{mol})$ (Fig. 4). Thus, the optimized protocol does

401 not alter $\mathrm{Mg} / \mathrm{Ca}$ and $\mathrm{Sr} / \mathrm{Ca}$ of reagent grade $\mathrm{CaCO}_{3}$, and we assumed the same occurred in

402 coccolithophore calcite. However, distribution of $\mathrm{Mg}$ in coccolithophore plates is unknown, thus

403 potential effects on partial dissolution remain open. Anand et al. (2003), Pak et al. (2004) and

404 Russell et al. (2004) applied stronger concentrations of $\mathrm{H}_{2} \mathrm{O}_{2}$-based oxidizing solutions during

405 longer time periods in organically enriched foraminifera samples, which suggests that optimization

406 tests based on variations in reactive concentration and time of incubation should be performed to

407 improve the organic removal efficiency. However, foraminifers' tests are about 10 times thicker

408 than coccoliths (Eggins et al., 2003; Young et al 2003). Therefore, potential higher dissolution

409 susceptibilities of coccolithophore calcite should be kept in mind. In addition to the chemical

410 treatment, previous manual separation and removal of organic material represents an important 
411 improvement in the final efficiency when removing organic $\mathrm{Mg}$ as demonstrated in treatment $\mathrm{F}$

412 (Fig. 1). Initial rinses with UP-water (Boyle, 1981) combined with ultrasonic bath, and removal of

413 visible organic phases by pipetting decreased the $\mathrm{P} / \mathrm{Ca}, \mathrm{Fe} / \mathrm{Ca}$, and $\mathrm{Mg} / \mathrm{Ca}$. Determination of $\mathrm{Mg} / \mathrm{Ca}$

414 and $\mathrm{Sr} / \mathrm{Ca}$ in this study were supported by the use of $\mathrm{P} / \mathrm{Ca}$ and $\mathrm{Fe} / \mathrm{Ca}$ (obtained simultaneously in

415 the elemental analysis via ICP-AES for the same sample) as indicators of organic matter

416 contamination. In addition, since all the ratios are normalized to $\mathrm{Ca}$, the sample concentration

417 should be openly provided in future studies to determine the reliability of the elemental ratios. Its

418 implementation does not require additional steps and we can consider it an indirect method to assess

419 the reliability of cleaning procedures in different laboratories. Fe/Ca and P/Ca should also be openly

420 provided in future geochemical studies as indicators of organic contamination to allow an accurate

421 results interpretation. They should be carefully considered as indicators of organic matter, although,

422 they may not have a unique relation with cleaning efficiency. For example, iron concentration,

423 which is not strictly associated with organic matter, greatly depends on the sample origin (cultures,

424 sediment traps, and natural community or sediment samples).

425 Sample characteristics such as the dry-weight of material and the species used are two

426 important factors that a priori might compromise the cleaning efficiency of organic $\mathrm{Mg}$ phases. The

427 volume of reagent applied should be proportional to the sample size to avoid sample loss associated

428 with pipetting during the intermediate rinses. Moreover, pellet weight should be kept within a small

429 range of variation when the volume of reagents is constant, otherwise this would compromise

430 reproducibility between samples. Additionally, the species-specific calcite/organic matter ratio

431 (PIC/POC) of coccolithophores (e.g. Langer et al., 2009b) may also be affecting the efficiency of

432 this protocol. For example, Emiliania huxleyi (PIC/POC 0.8), unlike C. leptoporus (PIC/POC >

433 2), requires the removal of larger proportions of organic matter. The later has lower initial

434 contribution of organic phases (relative to calcite), therefore, the fraction of elements removed 
435 during oxidative cleaning of organic phases was lower than in E. huxleyi (Table 3). The P/Ca

436 measured in C. leptoporus pellets $(0.40 \mathrm{mmol} / \mathrm{mol})$ was smaller that in $E$. huxleyi $(0.75 \mathrm{mmol} / \mathrm{mol})$,

437 reflecting the greater ease to effectively clean this species with higher ratio of calcite/organics.

438 Amongst the samples used in this study, E. huxleyi, with the lowest PIC/POC, and the smallest and 439 most structurally complex coccoliths, requires a more efficient removal of organic $\mathrm{Mg}$ than $C$.

440 leptoporus and G. oceanica.

441

\section{4.2. The elemental composition of coccolithophores}

443

The Mg/Ca of Emiliania huxleyi and Gephyrocapsa oceanica (Fig. 4) obtained in this study

445 were within the range of variation of previous data from batch cultures of the same species (Stoll et 446 al., 2001), with data from coccoliths obtained from sediment traps (Stoll et al., 2007), and with 447 cultured coccoliths cleaned with acetone and $\mathrm{H}_{2} \mathrm{O}_{2}$ (Ra et al., 2010). The much higher $\mathrm{Mg} / \mathrm{Ca}$ $448(2.710 \mathrm{mmol} / \mathrm{mol})$ measured in living cultures of E. huxleyi at present seawater conditions cleaned 449 with a bleach-based protocol (Müller et al., 2011), or in coccoliths of other cultured species for 450 which no cleaning is reported (Stanley et al., 2005) may be due to incomplete removal of

451 organically sourced $\mathrm{Mg}$. The lack of a robust and common cleaning protocol hampers inter-

452 laboratory comparisons to bring together different data sets, and thus advance the use of $\mathrm{Mg} / \mathrm{Ca}$ in 453 coccoliths.

454 We suggest that the recorded variation in coccolithophore $\mathrm{Mg} / \mathrm{Ca}$ in cleaned samples within 455 the species concept can be attributed to natural seawater variability. Ra et al. (2010) report, for 456 coccoliths treated with acetone $/ \mathrm{H}_{2} \mathrm{O}_{2}$-based protocol, $\mathrm{Mg} / \mathrm{Ca}$ between 0.029 and $0.051 \mathrm{mmol} / \mathrm{mol}$ in 457 E. huxleyi, and between 0.011 and $0.025 \mathrm{mmol} / \mathrm{mol}$ in G. oceanica, grown in seawater with a $458 \mathrm{Mg} / \mathrm{Ca}$ of $5.18 \mathrm{~mol} / \mathrm{mol}$. These data points fit on the regression implied by the $\mathrm{Mg} / \mathrm{Ca}$ of our 
459 coccoliths cultured in coastal seawater with $\mathrm{Mg} / \mathrm{Ca}$ of $5.670-5.827 \mathrm{~mol} / \mathrm{mol}$ (Fig. 5). Wild samples

460 of E. huxleyi obtained from the Bermuda Oceanic Flux Program (OFP) sediment traps, pre-treated

461 with $\mathrm{H}_{2} \mathrm{O}_{2}$ and analyzed with ion probe, yield comparable low values, although they are subjected

462 to higher uncertainty depending on the Mg blank in the epoxy mounting resin (Stoll et al., 2007).

463 Nonetheless, assuming oceanic waters in the North Atlantic Ocean have a Mg/Ca of $5.162 \mathrm{~mol} / \mathrm{mol}$

464 (Fabricand et al., 1967), the sediment trap samples off Bermuda fit the regression well (Fig. 5). It

465 reflects the variability of coccolithophore $\mathrm{Mg} / \mathrm{Ca}$ as a function of modern seawater $\mathrm{Mg} / \mathrm{Ca}$ of

466 different origins (e.g. coastal versus oceanic). This has been already observed for seawater $\mathrm{Mg} / \mathrm{Ca}$

467 (Fabricand et al., 1967; Zang et al., 2003) and Sr/Ca (de Villiers, 1999) showing latitudinal and

468 biogeographical variability, which we propose could drive the natural coccoliths composition and

469 may have implications for the sinking carbonates and the dissolution at depth. Further investigation

470 of deviations from the constant elemental proportions in seawater [Marcet's principle (1918)]

471 should aim to understand natural variability as a control of $\mathrm{Mg}$ and $\mathrm{Sr}$ in coccolithophores. The

472 number of coccolithophore samples and $\mathrm{Mg} / \mathrm{Ca}$ seawater ranges examined is relatively small;

473 therefore, a broader comparison is required to fully test this relationship, expanding from de Villiers

474 (1999) study on seawater $\mathrm{Sr} / \mathrm{Ca}$ to $\mathrm{Mg} / \mathrm{Ca}$ across large latitudinal gradients.

475 Interpretations of the $\mathrm{Mg} / \mathrm{Ca}$ variability based on published data are currently limited by: (1)

476 uncertainty in different organic $\mathrm{Mg}$ removal treatments applied, (2) variable medium conditions

477 (carbonate chemistry, seawater $\mathrm{Mg} / \mathrm{Ca}$ ), and (3) biological effect on elemental partitioning imposed

478 by the physiological fingerprint of species and strains used (Stanley et al., 2005; Müller et al.,

479 2011). For $\mathrm{Sr} / \mathrm{Ca}$ the situation is simpler because the organic contamination is minimal and $\mathrm{Sr} / \mathrm{Ca}$

480 measured in the three species (Fig. 4) were in agreement with values measured in culture samples

481 and sediment traps (Stoll et al., 2002; Stoll et al., 2007).

482 
The $\mathrm{Mg} / \mathrm{Ca}$ retrieved after organic phases removal were in accordance with bibliographic data and culture conditions. However, this study cannot guarantee that the removal of organic $\mathrm{Mg}$ was

487 truly complete. Further optimization work is needed, especially to work out the minimum amount of 488 sample required, whether the proportion of organic phases to calcite (PIC/POC) should be 489 considered when optimizing the protocols and SEM analyses to assess partial dissolution. The 490 protocol matrix could be extended by testing other organic removal methods such as combustion, 491 and the combination of acetone treatments ( $\mathrm{Ra}$ et al., 2010) with $\mathrm{H}_{2} \mathrm{O}_{2}$-based protocols. In order to

492 improve the yield of our protocol, we recommend introducing a manual separation of calcite (Fig.

493 1). The mechanical pre-selection before the chemical treatment enables to remove big

494 agglomerations of organic matter and concentrate efforts on removing organic material adhered to 495 calcite. While this technique prior to reduction and oxidation was not used before, it helps targeting 496 selectively the calcite fraction from the beginning of the protocol. In addition, the trace metal 497 concentration of the culture medium is an important factor in the formation of metal-oxides in 498 samples from living cultures. Thus, it is recommended to adjust the amount of trace metals added to 499 the minimum amount required without compromising phytoplankton growth rates (Boye and van 500 der Berg, 2000; Ho et al., 2003; Tang and Morel, 2006), to increase the efficiency of oxidizing 501 reagents. Additionally, in paleoceanographic applications it is better to target culture efforts on 502 species with high PIC/POC such as Calcidiscus sp., which also can be individually extracted from 503 sediments. Finally, to routinely measure $\mathrm{Mg} / \mathrm{Ca}$ in living coccolithophore material from laboratory 504 experiments and field samples, it is necessary to establish a series of baseline measures (quality 505 control) to make datasets comparable. Environmental conditions of growth and carbonate chemistry 506 in the culture media should always be provided because elemental partition (e.g. $\mathrm{D}_{\mathrm{Mg}}$ ) is affected by 
507 the carbonate chemistry (Ries, 2011) and seawater elemental composition (Ries, 2010; Müller et al.,

508 2011). Values of $\mathrm{Mg}$ removal efficiency, associated to organic phases, and the $\mathrm{P} / \mathrm{Ca}, \mathrm{Fe} / \mathrm{Ca}$ and $\mathrm{Ca}$

509 concentration should be provided along with the $\mathrm{Mg} / \mathrm{Ca}$ results to allow independent assessment

510 and comparison of datasets. In the short term, we should aim to calibrate the coccolithophore

$511 \mathrm{Mg} / \mathrm{Ca}$ as a proxy for temperature and study relationships to carbonate chemistry parameters (e.g.

$512 \mathrm{CO}_{3}{ }^{2-}$ ), contributing to the development of a coccolithophore multi-proxy approach. This will ease

513 more accurate estimations by reducing biases originating in different habitats, ecophysiology and

514 productivity regimes. We should also be able to understand coccolithophore $\mathrm{Mg} / \mathrm{Ca}$ and $\mathrm{Sr} / \mathrm{Ca}$

515 responses to environmental perturbations such as $p \mathrm{CO}_{2}$ and temperature variability, and investigate

516 other trace elements incorporated in the calcite and their potential biogeochemical applications.

517

518

519

520

521

522

523

524

525

526

527

528

529

530 
533 We thank three anonymous reviewers for their critical comments which significantly

534 improved the final draft of this manuscript. We also thank Ian Probert for providing Calcidiscus

535 leptoporus and culture advice, and Stephen Widdicombe for assisting in seawater collection. We are

536 also grateful to Tania Klüver for laboratory assistance and Julie LaRoche for allowing the use of

537 their laboratory facilities at Helmholtz Centre for Ocean Research Kiel (GEOMAR). This work was

538 funded by the "European Project on Ocean Acidification" (EPOCA) (which received funding from

539 the European Community's Seventh Framework Programme (FP7/2007-2013) under grant

540 agreement $\mathrm{n}^{\circ}$ 211384) for the PhD of ML and Abbey-Santander Internationalization Fund to SBA,

541 and ERC-STG-240222PACE for funding HS and AMV.

542

543

544

545

546

547

548

549

550

551

552

553

554 
556 Anand P., Elderfield H. and Conte M. H. (2003) Calibration of Mg/ca thermometry in planktonic

557 foraminifera from sediment trap time series. Paleoceanogr. 18, 1050.

558 Andersson A.J., Mackenzie F.T. and Bates N.R. (2008) Life on the margin: implications of ocean 559 acidification on Mg-calcite, high latitude and cold-water marine calcifiers. Mar. Ecol. Prog. $560 \quad$ Ser. 373, 265-273.

561 Barker S., Greaves M. and Elderfield H. (2003) A study of cleaning procedures used for 562 foraminiferal Mg/Ca paleothermometry. Geochem. Geophys. Geosyst. 4, 8407.

563 Barker S., Cacho I., Benway H. and Tachikawa K. (2005) Planktonic foraminiferal Mg/Ca as a 564 proxy for past oceanic temperatures: a methodological overview and data compilation for the 565 Last Glacial Maximum. Quaternary Sci. Rev. 24, 821-834.

566 Berelson W.M., Balch W.M., Najjar R., Feely R.A, Sabine C. and Lee K. (2007) Relating estimates of $\mathrm{CaCO}_{3}$ production, export, and dissolution in the water column to measurements of $\mathrm{CaCO}_{3}$ rain into sediment traps and dissolution on the sea floor: a revised global carbonate budget. Glob. Biogeochem. Cy. 21, GB1024.

570 Bian N. and Martin P.A. (2010) Investigating the fidelity of $\mathrm{Mg} / \mathrm{Ca}$ and other elemental data from reductively cleaned planktonic foraminifera. Paleoceanogr. 25, PA2215.

572 Bown P.R., Lees J.A. and Young J.R. (2004) Calcareous nannoplankton evolution and diversity 573 through time. In Coccolithophores: From Molecular Processes to Global Impact (eds. H. 574 Thierstein, and J.R. Young). Springer Verlag Berlin Heidelberg, Germany. pp. 481-508.

575 Boye, M. and van der Berg C.G. (2000) Iron availability and the release of iron-complexing ligands by Emiliania huxleyi. Mar. Chem. 70, 277-287.

577 Boyle E.A. (1981) Cadmium, Zinc, Copper, and Barium in foraminifera tests. Earth Plan. Sci. Lett. 578 53, 11-35. 
579 Boyle E.A. (1983) Manganese carbonate overgrowths on foraminifera tests. Geochim. Cosmochim.

$580 \quad$ Ac. $47,1815-1819$.

581 Chereskin B.M., Wong Y.-S. and Castelfranco, P.A. (1982) In vitro synthesis of the chlorophyll

582 isocyclic ring: Transformation of magnesium-protoporphyrin IX and magnesium-

583 protoporphyrin IX monomethyl ester into magnesium-2,4-divinyl pheoporphyrin a5. Plant

$584 \quad$ Physiol. 70, 987-993.

585 Chu S.P. (1946) The utilization of organic phosphorus by phytoplankton. J. Mar. Biol. Assoc. UK.

586 26, 258-295.

587 Eggins S., De Deckker P. and Marschall J. (2003) Mg/Ca variation in planktonic foraminifera tests:

588 implications for reconstructing palaeo-seawater temperature and habitat migration. Earth

$589 \quad$ Planet. Sci. Lett. 212, 291-306.

590 Fabricand B. P., Imbimbo E. S. and Brey M. E. (1967) Atomic absorption analyses for Ca, Li, K, $591 \quad \mathrm{Rb}$, and Sr at two Atlantic Ocean stations. Deep-Sea Research. 14, 185-189.

592 Feely R.A., Sabine C.L., Lee K., Berelson W., Kleypas J., Fabry V.J. and Millero F.J. (2004)

593 Impact of Anthropogenic $\mathrm{CO}_{2}$ on the $\mathrm{CaCO}_{3}$ System in the Oceans. Science. 305, 362-366.

594 Francois R., Honjo S., Krishfield R. and Manganini S. (2002) Factors controlling the flux of organic 595 carbon to the bathypelagic zone of the ocean. Glob. Biogeochem. Cy. 16, 1887.

596 Gattuso J.-P., Gao K., Lee K., Rost B. and Schulz K.G. (2010) Approaches and tools to manipulate 597 the carbonate chemistry. In EPOCA Guide to best practices in ocean acidification research 598 and data reporting (eds. Riebesell U., Fabry V.J., Hansson L. and Gattuso J.-P. ), EUR 24328 599 EN, European Commission, Belgium. pp. 41-52.

600 Gehlen M., Gangst $\varnothing$ R., Schneider B., Bopp L., Aumont O. and Ethe C. (2007) The fate of pelagic $601 \quad \mathrm{CaCO}_{3}$ production in a high $\mathrm{CO}_{2}$ ocean: a model study. Biogeosci. 4, 505-519. 
602 Guillard R.R.L. and Ryther J.H. (1962) Studies of marine planktonic diatoms: 1. Cyclotella nana 603 (Hustedt) and Detonula confervacea (Cleve Gran). Can. J. Microbiol. 8, 229-239.

604 Guillard R.R.L. (1975) Culture of phytoplankton for feeding marine invertebrates. In Culture of 605 Marine Invertebrate Animals (eds. W.L. Smith and M.H. Chaney). Plenum Press, New York. 606 pp. 29-60.

607 Harris R. J.C. (1954) Biological applications of freezing and drying. Academic Press. New York. 608 Ho T.-Y., Quigg A., Finkel Z.V., Milligan A.J., Wyman K., Falkowski P.G. and Morel F.M.M. 609 (2003) The elemental composition of some marine phytoplankton. J. Phycol. 39, 1145-1159.

610 Iglesias-Rodriguez M.D., Halloran P.R., Rickaby R.E. M, Hall I.R., Colmenero-Hidalgo E., Gittins 611 J.R., Green D.R.H., Tyrrell T., Gibbs S.J., von Dassow P., Rehm E., Armbrust E.V. and 612 Boessenkool K.P. (2008) Phytoplankton Calcification in a High-CO ${ }_{2}$ World. Science. 320, $613 \quad 336-340$.

614 Kester D., Duedall I., Connors D. and Pytkowicz R. (1967) Preparation of artificial seawater. 615 Limnol. Oceanogr. 12, 176-179.

616 Key R.M., Kozyr A., Sabine C.L., Lee K., Wanninkhof R., Bullister J.L., Feely R.A., Millero J.A., 617 Mordy C. and Peng T.H. (2004) A global ocean carbon climatology: Results from Global 618 Data Analysis Project (GLODAP). Global Biogeochem. Cy. 18, GB4031.

619 Kroh A. and Nebelsick J.H. (2010) Echinoderms and Oligo-Miocene carbonate systems: potential 620 applications in sedimentology and environmental reconstruction. Int. Assoc. Sedimentol. Spec. $621 \quad$ Publ. 42, 201-228.

622 Kuffner I.B., Andersson A.J., Jokiel P.L., Rodgers K.S. and Mackenzie F.T. (2007) Decreased 623 abundance of crustose coralline algae due to ocean acidification. Nature Geosci. 1, 114-117. 624 Langer G., Gussone N., Nehrke G., Riebesell U., Eisenhauer A., Kuhnert H., Rost B., Trimborn S. 625 and Thoms S. (2006a) Coccolith strontium to calcium ratios in Emiliania huxleyi: The 
626 dependence on seawater strontium and calcium concentrations. Limnol. Oceanogr. 51, 310$627 \quad 320$.

628 Langer G., Geisen M., Baumann K.- H., Kläs J., Riebesell U., Thoms S. and Young J.R. (2006b). 629 Species-specific responses of calcifying algae to changing seawater carbonate chemistry. $630 \quad$ Geochem. Geophys. Geosyst. 7, Q09006.

631 Langer G., Nehrke G., Thoms S. and Stoll H. (2009a) Barium partitioning in coccoliths of 632 Emiliania huxleyi. Geochim. Cosmochim. Ac. 73, 2899-2906.

633 Langer G., Nehrke G., Probert I., Ly J. and Ziveri P. (2009b) Strain-specific responses of Emiliania 634 huxleyi to changing seawater carbonate chemistry. Biogeosci. 6, 2637-2646.

635 Legong L., Tutone A.F., Drummond R.S.M., Gardner R.C. and Luan S. (2001) A novel family of 636 magnesian transport genes in Arabidopsis. Plant Cell. 13, 2761-2775.

637 Leroy J. (1926) Necessite du magnesium pour la croissance de la souris. Comptes Rendus Seances $638 \quad$ Soc. Biol. 94, 431-433.

639 Lusk J.E., Williams R.J.P. and Kennedy E.P. (1968) Magnesium and the Growth of Escherichia $640 \quad$ coli. J. Biol. Chem. 243, 2618-2624.

641 Marcet A. (1918) On the Specific Gravity, and Temperature of Sea Waters, in Different Parts of the 642 Ocean, and in Particular Seas; With Some Account of Their Saline Contents. Philos. Trans. $R$. $643 \quad$ Soc. Lond. 109, 161-208.

644 Martin P.A. and Lea D.W. (2002) A simple evaluation of cleaning procedures on fossil benthic 645 foraminiferal Mg/Ca. Geochem. Geophys. Geosyst. 10, doi:10.1029/2001GC000280

646 Morse J.W. and Bender L.M. (1990) Partition coefficients in calcite: Examination of factors 647 influencing the validity of experimental results and their application to natural systems. Chem. $648 \quad$ Geol. 82, 265-277. 
649 Morse J.W. Andersson A.J. and Mackenzie F.T. (2006) Initial responses of carbonate-rich shelf 650 sediments to rising atmospheric $p \mathrm{CO}_{2}$ and “ocean acidification": Role of high $\mathrm{Mg}$-calcites. 651 Geochim. Cosmochim. Ac. 70, 5814-5830.

652 Mucci A. and Morse, J.W. 1987. The incorporation of $\mathrm{Mg}^{2+}$ and $\mathrm{Sr}^{2+}$ into calcite overgrowths: 653 influences of growth rate and solution composition. Geochim. Cosmochim. Ac. 47, 217-233. 654 Müller M.N., Kisakürek B., Buhl D., Gutperlet R., Kolevica A., Riebesell U., Stoll H. and 655 Eisenhauer A. (2011) Response of the coccolithophores Emiliania huxleyi and Coccolithus 656 braarudii to changing $\mathrm{Mg}^{2+}$ and $\mathrm{Ca}^{2+}$ concentrations: $\mathrm{Mg} / \mathrm{Ca}, \mathrm{Sr} / \mathrm{Ca}$ ratios and $\delta^{44 / 40} \mathrm{Ca}$, $\delta^{26 / 24} \mathrm{Mg}$ of coccolith calcite. Geochim. Cosmochim. Ac. 75, 2088-2102.

658 Pak D. K., Lea D. W. and Kennett J. P. (2004) Seasonal and interannual variation in Santa Bárbara 659 Basin water temperatures observed in sediment trap foraminifera $\mathrm{Mg} / \mathrm{Ca}$. Geochem. Geophy. $660 \quad$ Geosys. 5 (12), Q12008.

661 Pierrot D., Lewis E. and Wallace D. W. R. (2006) MS Excel Program Developed for CO2 System 662 Calculations. ORNL/CDIAC-105a. Carbon Dioxide Information Analysis Center, Oak Ridge 663 National Laboratory, U.S. Department of Energy, Oak Ridge, Tennessee.

$664 \mathrm{Ra} \mathrm{K}$., Kitagawa H. and Shiraiwa Y. (2010) Mg isotopes and Mg/Ca values of coccoliths from 665 cultured specimens of the species Emiliania huxleyi and Gephyrocapsa oceanica. Mar. $666 \quad$ Micropaleontol. 77, 119-124.

667 Ridgwell A., Schmidt D.N., Turley C., Brownlee C., Maldonado M.T., Tortell P. and Young J.R. 668 (2009) From laboratory manipulations to Earth system models: scaling calcification impacts 669 of ocean acidification. Biogeosci. 6, 2611-2623.

670 Ries J.B. (2010) Geological and experimental evidence for secular variation in seawater $\mathrm{Mg} / \mathrm{Ca}$ 671 (calcite- aragonite seas) and its effects on marine biological calcification. Biogeosci. 7, 2795672 2849. 
673 Ries J.B. (2011) Skeletal mineralogy in a high-CO2 world. J. Exp. Mar. Biol. Ecol. 403, 54-64.

674 Rue E.L. and Bruland K.W. (1997) The role of organic complexation on ambient iron chemistry in 675 the equatorial Pacific Ocean and the response of a mesoscale iron addition experiment. $676 \quad$ Limnol. Oceanogr., 42, 901-910.

677 Russell A. D., Hönisch B., Spero H. J. and Dea D. W. (2004) Effects of seawater carbonate ion 678 concentration and temperature on shell $\mathrm{U}, \mathrm{Mg}$, and $\mathrm{Sr}$ in cultured planktonic foraminifera. 679 Geochim. Cosmochim. Ac. 68, 4347-4361.

680 Sharp J.H. (1974) Improved analysis for particulate organic carbon and nitrogen from seawater. 681 Limnol. Oceanogr. 19, 984-989.

682 Siesser W.G. (1977) Chemical composition of calcareous nannofossils. S. Afr. J. Sci. 73, 283.

683 Stanier R.Y. and Smith J.H.C. (1959) Carnegie Inst. Wash. Yearbook. 58. pp. 336.

684 Stanley S.M., Ries J.B. and Hardie L.A. (2005) Seawater chemistry, coccolithophore population 685 growth, and the origin of Cretaceous chalk. Geology 33, 593-596.

686 Stoll H.M. and D.P. Schrag (2000) Coccolith $\mathrm{Sr} / \mathrm{Ca}$ as a new indicator of coccolithophorid 687 calcification and growth rate. Geochem. Geophys. Geosyst. 1, 1006.

688 Stoll H.M., Ruiz Encinar J., Garcia Alonso J.I., Rosenthal Y., Probert I. and Klaas C. (2001) A first 689 look at paleotemperature prospects from $\mathrm{Mg}$ in coccolith carbonate: Cleaning techniques and $690 \quad$ culture measurements. Geochem. Geophys. Geosyst. 2.

691 Stoll H.M., Klaas C.M., Probert I., Ruiz Encinar J. and Garcia Alonso I. (2002) Calcification rate 692 and temperature effects on Sr partitioning in coccoliths of multiple species of 693 coccolithophorids in culture. Global Planet. Change. 34, 153-171.

694 Stoll H.M. and Ziveri P. (2004) Coccolithophorid-based geochemical paleoproxies. In 695 Coccolithophores: From Molecular Processes to Global Impact (eds. H. Thierstein, and J.R. 696 Young). Springer Verlag Berlin Heidelberg, Germany. pp. 529-562. 
697 Stoll H.M., Shimizu N., Archer D. and Ziveri P. (2007) Coccolithophore productivity response to 698 greenhouse event of the Paleocene-Eocene Thermal Maximum. Earth Planet. Sci. Lett. 258, $699 \quad$ 192-206.

700 Tang D. and Morel F.M.M. (2006) Distinguishing between cellular and Fe-oxide-associated trace 701 elements in phytoplankton. Mar. Chem. 98, 18-30.

702 Tesoriero A.J. and Pankow J.F. (1996) Solid solution partitioning of $\mathrm{Sr}^{2+}, \mathrm{Ba}^{2+}$, and $\mathrm{Cd}^{2+}$ to calcite. 703 Geochim. Cosmochim. Ac. 60, 1053-1063.

704 de Vargas C., Saez A.G., Medlin L.K and Thierstein H.R. (2004) Super-species in the calcareous 705 plankton. In Coccolithophores: From Molecular Processes to Global Impact (eds. H.

706 Thierstein, and J.R. Young). Springer Verlag Berlin Heidelberg, Germany. pp. 271-299.

707 de Villiers S. (1999) Seawater strontium and Sr/Ca variability in the Atlantic and Pacific oceans.

$708 \quad$ Earth Planet. Sci. Lett. 171, 623-634.

709 de Villiers S., Greaves M. and Elderfield H. (2002) An intensity ratio calibration method for the 710 accurate determination of $\mathrm{Mg} / \mathrm{Ca}$ and $\mathrm{Sr} / \mathrm{Ca}$ of marine carbonates by ICP-AES. Geochem. 711 Geophys. Geosyst. 3.

$712 \mathrm{Wu}$ J. and Luther G.W. (1995) Complexation of iron(III) by natural organic ligands in the 713 Northwest Atlantic Ocean by a competitive ligand equilibration method and a kinetic $714 \quad$ approach. Mar. Chem. 50, 159-177.

715 Young J. R., Geisen M., Cros L., Kleijne A., Sprengel C., Probert I. and Østergaard J. B. (2003) A 716 guide to extant coccolithophore taxonomy. J. Nannoplankton Res. Special issue $\mathbf{1}$.

717 Yu J., Elderfield H., Greaves M. and Day J. (2007) Preferential dissolution of benthic foraminiferal 718 calcite during laboratory reductive cleaning. Geochem. Geophys. Geosyst. 8, Q06016. 
719 Zang W., Dai X., Jiang M., Yao Q., Cai Y., Luo C., Xu G. and Ding F. (2003) The influences of $720 \mathrm{Mg}^{2+}, \mathrm{Ca}^{2+}$ and $\mathrm{Mg}^{2+} / \mathrm{Ca}^{2+}$ ratio in mixed seawater on the emergence rate of Penaeus $721 \quad$ japonicus postlarva. Chin J. Oceanol. Linmol. 21, 78-85. 


\section{TABLES}

Table 1. Culture conditions, medium chemistry and sample parameters of coccolithophores in experimental cultures.

\begin{tabular}{|c|c|c|c|c|c|c|}
\hline Species & Chlorella autotrophica ${ }^{\mathrm{a}}$ & \multicolumn{2}{|c|}{ Emiliania huxleyi $^{\mathrm{b}}$} & \multicolumn{2}{|c|}{ Calcidiscus leptoporus ${ }^{\mathrm{b}}$} & Gephyrocapsa oceanica $^{\mathrm{c}}$ \\
\hline Strain & CCMP243 & \multicolumn{2}{|c|}{ CAWPO6 (NZEH) } & \multicolumn{2}{|c|}{ RCC1169 } & RCC1303 \\
\hline Location & North Atlantic & \multicolumn{2}{|c|}{ New Zealand } & \multicolumn{2}{|c|}{ Mediterranean Sea } & North Atlantic \\
\hline Latitude & $43.41^{\circ} \mathrm{N}$ & \multicolumn{2}{|c|}{$46.58^{\circ} \mathrm{S}$} & \multicolumn{2}{|c|}{$43.41^{\circ} \mathrm{N}$} & $44.60^{\circ} \mathrm{N}$ \\
\hline Longitude & $73.10^{\circ} \mathrm{W}$ & \multicolumn{2}{|c|}{$168.05^{\circ} \mathrm{E}$} & \multicolumn{2}{|c|}{$7.19^{\circ} \mathrm{E}$} & $1.5^{\circ} \mathrm{W}$ \\
\hline \multicolumn{7}{|l|}{ Culture conditions ${ }^{\mathrm{d}}$} \\
\hline Temperature $\left({ }^{\circ} \mathrm{C}\right)$ & $19.90 \pm 0.18$ & \multicolumn{2}{|c|}{$18.49 \pm 0.31$} & \multicolumn{2}{|c|}{$20.09 \pm 0.10$} & $20.00 \pm 0.00$ \\
\hline $\operatorname{PAR}\left(\mu\right.$ mol quanta $\left.\mathrm{m}^{-2} \mathrm{~s}^{-1}\right)$ & $130.57 \pm 2.71$ & \multicolumn{2}{|c|}{$123 \pm 4$} & \multicolumn{2}{|c|}{$133 \pm 5$} & $150 \pm 0.00$ \\
\hline Salinity & $35 \pm 0.00$ & \multicolumn{2}{|c|}{$35.2 \pm 0.1$} & \multicolumn{2}{|c|}{$35.0 \pm 0.1$} & $35.0 \pm 0.1$ \\
\hline Nitrate $(\mu \mathrm{M})$ & $100 \pm 0.00$ & \multicolumn{2}{|c|}{$95.25 \pm 0.00$} & \multicolumn{2}{|c|}{$94.33 \pm 0.00$} & $58.80 \pm 3.09$ \\
\hline Phosphate $(\mu \mathrm{M})$ & $6.40 \pm 0.00$ & \multicolumn{2}{|c|}{$4.88 \pm 0.00$} & \multicolumn{2}{|c|}{$2.82 \pm 0.00$} & $6.28 \pm 0.21$ \\
\hline \multicolumn{7}{|c|}{ Medium carbonate chemistry ${ }^{\mathrm{d}}$} \\
\hline & & $\mathrm{t}_{0}$ & $\mathrm{t}_{n}$ & $\mathrm{t}_{0}$ & $\mathrm{t}_{n}$ & $\mathrm{t}_{0}$ \\
\hline $\mathrm{TA}\left(\mu \mathrm{mol} \mathrm{kg}{ }^{-1}\right)$ & - & $2272.7^{\mathrm{e}}$ & $2242.7 \pm 1.7$ & $2234.5^{\mathrm{e}}$ & $1555.3 \pm 817.8$ & $2343.5 \pm 1.9^{f}$ \\
\hline $\operatorname{DIC}\left(\mu \mathrm{mol} \mathrm{kg}^{-1}\right)$ & - & $2131.1^{\mathrm{e}}$ & $2046.5 \pm 3.7$ & $2031.6^{\mathrm{e}}$ & $1456.1 \pm 58.5$ & $2081.7 \pm 10.8^{\mathrm{g}}$ \\
\hline $\mathrm{pH}_{\text {total }}$ & $8.13 \pm 0.04$ & 7.82 & $7.95 \pm 0.01$ & 7.94 & $7.75 \pm 0.03$ & $8.05 \pm 0.02$ \\
\hline 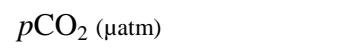 & - & 722.0 & $506.3 \pm 8.4$ & 512.4 & $585.6 \pm 41.3$ & $408.4 \pm 26.8$ \\
\hline $\mathrm{HCO}_{3}^{-}\left(\mu \mathrm{mol} \mathrm{kg}^{-1}\right)$ & - & 1994.2 & $1886.0 \pm 5.0$ & 1866.7 & $1367.3 \pm 3.9$ & $1880.1 \pm 18.6$ \\
\hline $\mathrm{CO}_{3}^{2-}\left(\mu \mathrm{mol} \mathrm{kg}{ }^{-1}\right)$ & - & 112.5 & $143.5 \pm 1.6$ & 148.4 & $69.9 \pm 5.3$ & $188.4 \pm 8.6$ \\
\hline $\mathrm{CO}_{2}\left(\mu \mathrm{mol} \mathrm{kg}{ }^{-1}\right)$ & - & 24.3 & $17.0 \pm 0.3$ & 16.5 & $18.9 \pm 1.3$ & $13.2 \pm 0.9$ \\
\hline$\Omega$ Calcite & - & 2.68 & $3.43 \pm 0.03$ & 3.55 & $1.67 \pm 0.13$ & $4.51 \pm 0.21$ \\
\hline Seawater $\mathrm{Mg} / \mathrm{Ca}(\mathrm{mol} / \mathrm{mol})^{\mathrm{h}}$ & & $5.67 \pm 0.03$ & $5.67 \pm 0.03$ & $5.40 \pm 0.03$ & $5.83 \pm 0.04$ & $5.63 \pm 0.02^{\mathrm{i}}$ \\
\hline Seawater $\mathrm{Sr} / \mathrm{Ca}(\mathrm{mmol} / \mathrm{mol})^{\mathrm{h}}$ & & $8.59 \pm 0.04$ & $8.61 \pm 0.07$ & $8.72 \pm 0.06$ & $8.87 \pm 0.05$ & $7.95 \pm 0.08^{\mathrm{i}}$ \\
\hline \multicolumn{7}{|l|}{ Sample parameters ${ }^{\mathrm{d}}$} \\
\hline Cell density $\left(\right.$ cell ml $\left.{ }^{-1}\right)$ & $1.51 \cdot 10^{6} \pm 5.08 \cdot 10^{5}$ & \multicolumn{2}{|c|}{$33890 \pm 2009$} & \multicolumn{2}{|c|}{$9066 \pm 945$} & $25000-50000^{k}$ \\
\hline Growth rate $(\mu)$ & $0.73 \pm 0.042$ & \multicolumn{2}{|c|}{$1.45 \pm 0.015$} & \multicolumn{2}{|c|}{$0.37 \pm 0.009$} & $0.91 \pm 0.120$ \\
\hline PIC quota (pg C cell ${ }^{-1}$ ) & - & \multicolumn{2}{|c|}{$6.42 \pm 0.89^{\mathrm{j}}$} & \multicolumn{2}{|c|}{$433.87 \pm 49.48^{\mathrm{j}}$} & $28.00 \pm 2.80^{1}$ \\
\hline PIC prod. (pg C cell ${ }^{-1} \mathrm{~d}^{-1}$ ) & - & \multicolumn{2}{|c|}{$9.35 \pm 1.25 \mathrm{j}$} & 162 . & $14.58^{\mathrm{j}}$ & $25.31 \pm 1.02^{1}$ \\
\hline POC quota (pg C cell $\left.{ }^{-1}\right)$ & - & & 1.04 & & \pm 1.77 & $26.85 \pm 0.49$ \\
\hline POC prod. (pg C cell ${ }^{-1} \mathrm{~d}^{-1}$ ) & - & & 1.41 & & 1.31 & $11.14 \pm 0.34$ \\
\hline PIC:POC (wt:wt) & - & & 0.07 & & 0.23 & $1.92 \pm 0.14$ \\
\hline $\mathrm{C}: \mathrm{N}$ (mol:mol) & - & & 0.04 & & 0.12 & $11.14 \pm 0.01$ \\
\hline
\end{tabular}


(a) Non-calcifying algae used for synthetic pellet preparation along with pure calcite. Medium carbonate chemistry only recorded as $\mathrm{pH}_{\text {total. }}$.

(b) Strains cultured in natural seawater.

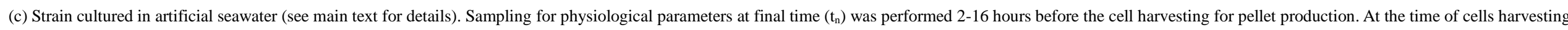
the culture are expected being in exponential growth phase, therefore the lag between sampling and cell harvesting should not affect the physiological parameters.

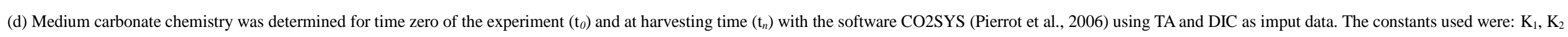

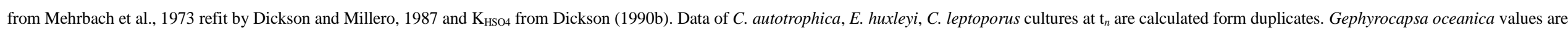
the average from two $\mathrm{CO}_{2}$ conditions ( 381 and $496 \mu \mathrm{atm}$ ) sampled one day before harvesting the pellets. Initial and final conditions are presented as an average of both replicates.

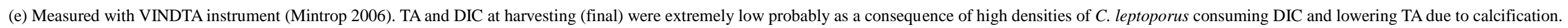

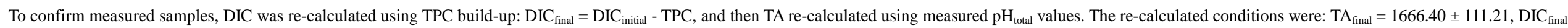
$=1500.76 \pm 100.72$. These conditions do not affect the work on the cleaning of organic Mg and the subsequent ICP-AES measurements.

(f) TA measured in a Metrohm Basic Titrino 794 titration device.

(g) DIC measured photometrically in a QUAATRO analyzer (Stoll et al., 2001).

(h) Standard error calculated form duplicate measurements of the same sample analysed with ICP-AES.

(i) Sample was collected 2-16 hours before the cell harvesting.

(j) PIC measured as calcite with an ICP-AES and obtained values where corrected for contribution of seawater salts (see main text for details).

(k) Cell density was not measured at harvesting time. These values indicate the range of variation estimated.

(1) PIC measured from: PIC = TPC - POC, with an elemental analyzer Euro EA (Sharp, 1974) 
Table 2. A summary of protocols tested, elemental ratios, and cleaning efficiencies on Chlorella autotrophica and calcite pellets.

\begin{tabular}{|c|c|c|c|c|c|c|c|c|}
\hline Protocol code & $\mathbf{A}$ & $\mathbf{B}$ & $\mathbf{C}$ & D & $\mathbf{E}$ & $\mathbf{F}$ & $\mathbf{G}$ & $\mathbf{H}^{\mathrm{d}}$ \\
\hline Cleaning protocol & Bleach $^{\mathrm{a}}$ & Bleach & $\begin{array}{l}\text { Red. }^{\text {b }} \\
\text { Bleach }^{2}\end{array}$ & Oxid. $^{\mathrm{c}}$ & $\begin{array}{l}\text { Red. } \\
\text { Oxid. }\end{array}$ & Oxid. & $\begin{array}{l}\text { Red. } \\
\text { Oxid. }\end{array}$ & $\begin{array}{l}\text { Red. } \\
\text { Oxid. }\end{array}$ \\
\hline Pellet $n^{\circ}$ & $(1-6)$ & $(1-6)$ & $(7-8)$ & $(9-11)$ & $(12-14)$ & $(12-14)$ & (15) & (16) \\
\hline \multicolumn{9}{|l|}{ Pre-treatment } \\
\hline Rinses UP $\mathbf{P}^{\mathrm{e}}$ & - & - & - & - & - & x6 & $\mathrm{x} 5$ & $\mathrm{x} 3$ \\
\hline Volume (ml) & - & - & - & - & - & 2 & 2 & 2 \\
\hline \multicolumn{9}{|c|}{ Reduction + Oxidation } \\
\hline Reduction & - & - & Red. & - & Red. & - & Red. & Red. \\
\hline Volume (ml) & - & - & 1 & - & 0.350 & - & 0.750 & 0.750 \\
\hline Sonication (min.) & - & - & 15 & - & 15 & - & 20 & 20 \\
\hline Incubation (h) & - & - & 24 & - & 24 & - & 24 & 24 \\
\hline Temperature $\left({ }^{\circ} \mathrm{C}\right)$ & - & - & 22 & - & 22 & - & 22 & 22 \\
\hline Rinse UP & - & - & $\mathrm{x} 2$ & - & $\mathrm{x} 4$ & - & $\mathrm{x} 4$ & $\mathrm{x} 4$ \\
\hline Volume (ml) & - & - & 2 & - & 2 & - & 2 & 2 \\
\hline $1^{\text {st }}$ Oxidation & Bleach & Bleach & Bleach & Oxid. & Oxid. & Oxid. & Oxid. & Oxid. \\
\hline Volume (ml) & 2 & 2 & 2 & 3 & 3 & 3 & 2 & 2 \\
\hline Sonication (min) & 15 & 15 & 15 & 10 & 10 & 10 & 10 & 10 \\
\hline Incubation & $24 \mathrm{~h}$ & $24 \mathrm{~h}$ & $24 \mathrm{~h}$ & $10 \mathrm{~min}$ & $10 \mathrm{~min}$ & $10 \mathrm{~min}$ & $10 \mathrm{~min}$ & $10 \mathrm{~min}$ \\
\hline Temperature $\left({ }^{\circ} \mathrm{C}\right)$ & 22 & 22 & 22 & 100 & 100 & 100 & 100 & 100 \\
\hline Rinse UP & $\mathrm{x} 2$ & $\mathrm{x} 2$ & $\mathrm{x} 2$ & $\mathrm{x} 3$ & $\mathrm{x} 3$ & $\mathrm{x} 3$ & $\mathrm{x} 2$ & $\mathrm{x} 2$ \\
\hline Volume (ml) & 2 & 2 & 2 & 2 & 2 & 2 & 2 & 1 \\
\hline $2^{\text {nd }}$ Oxidation & Bleach & Bleach & Bleach & Oxid. & Oxid. & Oxid. & Oxid. & Oxid. \\
\hline Volume (ml) & 2 & 2 & 2 & 3 & 3 & 3 & 1 & 1 \\
\hline Sonication (min) & 15 & 15 & 15 & 10 & 10 & 10 & 10 & 10 \\
\hline Incubation & $24 \mathrm{~h}$ & $24 \mathrm{~h}$ & $24 \mathrm{~h}$ & $10 \mathrm{~min}$ & $10 \mathrm{~min}$ & $10 \mathrm{~min}$ & $10 \mathrm{~min}$ & $10 \mathrm{~min}$ \\
\hline Temperature $\left({ }^{\circ} \mathrm{C}\right)$ & 22 & 22 & 22 & 100 & 100 & 100 & 100 & 100 \\
\hline Rinse UP & $\mathrm{x} 2$ & $\mathrm{x} 2$ & $\mathrm{x} 2$ & $\mathrm{x} 3$ & $\mathrm{x} 3$ & $\mathrm{x} 3$ & $\mathrm{x} 2$ & $x 2$ \\
\hline Volume (ml) & 2 & 2 & 2 & 2 & 2 & 2 & 2 & 1 \\
\hline $3^{\text {rd }}$ Oxidation & Bleach & Bleach & Bleach & Oxid. & Oxid. & Oxid. & Oxid. & Oxid. \\
\hline Volume (ml) & 2 & 2 & 2 & 1.5 & 1.5 & 1.5 & 1 & 1 \\
\hline Sonication (min) & 15 & 15 & 15 & 10 & 10 & 10 & 10 & 10 \\
\hline Incubation & $24 \mathrm{~h}$ & $24 \mathrm{~h}$ & $24 \mathrm{~h}$ & $10 \mathrm{~min}$ & $10 \mathrm{~min}$ & $10 \mathrm{~min}$ & $10 \mathrm{~min}$ & $10 \mathrm{~min}$ \\
\hline Temperature $\left({ }^{\circ} \mathrm{C}\right)$ & 22 & 22 & 22 & 100 & 100 & 100 & 100 & 100 \\
\hline Rinse UP & $\mathrm{x} 2$ & $\mathrm{x} 2$ & $\mathrm{x} 2$ & $\mathrm{x} 3$ & $\mathrm{x} 3$ & $\mathrm{x} 3$ & $\mathrm{x} 2$ & $\mathrm{x} 2$ \\
\hline Volume (ml) & 2 & 2 & 2 & 2 & 2 & 2 & 2 & 1 \\
\hline $4^{\text {th }}$ Oxidation & Bleach & Bleach & Bleach & Oxid. & Oxid. & Oxid. & Oxid. & - \\
\hline Volume (ml) & 2 & 2 & 2 & 0.5 & 0.5 & 0.5 & 1 & - \\
\hline Sonication (min) & 15 & 15 & 15 & 10 & 10 & 10 & 10 & - \\
\hline Incubation & $24 \mathrm{~h}$ & $24 \mathrm{~h}$ & $24 \mathrm{~h}$ & $10 \mathrm{~min}$ & $10 \mathrm{~min}$ & $10 \mathrm{~min}$ & $10 \mathrm{~min}$ & - \\
\hline Temperature $\left({ }^{\circ} \mathrm{C}\right)$ & 22 & 22 & 22 & 100 & 100 & 100 & 100 & - \\
\hline Rinse UP & $\mathrm{x} 4$ & $\mathrm{x} 2$ & $\mathrm{x} 4$ & $\mathrm{x} 4$ & $\mathrm{x} 4$ & $\mathrm{x} 4$ & $\mathrm{x} 4$ & - \\
\hline Volume (ml) & 2 & 2 & 2 & 1 & 1 & 1 & 1 & - \\
\hline $5^{\text {th }}$ Oxidation & - & Bleach & - & - & - & - & - & - \\
\hline Volume (ml) & - & 2 & - & - & - & - & - & - \\
\hline Sonication (min) & - & 15 & - & - & - & - & - & - \\
\hline Incubation & - & $24 \mathrm{~h}$ & - & - & - & - & - & - \\
\hline Temperature $\left({ }^{\circ} \mathrm{C}\right)$ & - & 22 & - & - & - & - & - & - \\
\hline Rinse UP & - & $\mathrm{x} 4$ & - & - & - & - & - & - \\
\hline Volume (ml) & - & 2 & - & - & - & - & - & - \\
\hline Protocol time $^{f}$ & $96 \mathrm{~h}$ & $120 \mathrm{~h}$ & $120 \mathrm{~h}$ & $40 \mathrm{~min}$ & $24.6 \mathrm{~h}$ & $40 \min$ & $24.6 \mathrm{~h}$ & $24.5 \mathrm{~h}$ \\
\hline
\end{tabular}

(a) Oxidation solution: $10 \% \mathrm{NaClO}(\mathrm{v} / \mathrm{v})$.

(b) Reduction solution: $4.76 \%$ (v/v) Hydroxylamine-hydrochloride $\mathrm{NH}_{2} \mathrm{OH} \cdot \mathrm{HCl}+38 \%$ (v/v) $\mathrm{NH}_{4} \mathrm{OH}$.

(c) Oxidation solution: $0.33 \%(\mathrm{v} / \mathrm{v}) \mathrm{H}_{2} \mathrm{O}_{2}+0.98 \%$ (v/v) $\mathrm{NaOH}$. 
(d) Protocol H was used to treat all coccolith samples.

(e) UP stands for alkaline ultra pure water rinses, which $\mathrm{pH}_{\text {total }}$ was adjusted between 9 and 10 with $\mathrm{NH}_{4} \mathrm{OH}$ to avoid carbonate dissolution. After the rinses all pellets were centrifuged at $3000 \mathrm{rpm}$ for 10 minutes and the supernatant was removed. Time for incubations only. This excludes handling and preparation for ICP-AES.

(f) Time of incubations only. This excludes handling and preparation for ICP-AES analyzes. 
Table 3. Target elemental ratios measured in non-treated samples and the pellets treated with the optimized cleaning protocol $\mathrm{H}$, and estimation of sample recovery.

\begin{tabular}{|c|c|c|c|c|}
\hline & Non-treated samples ${ }^{a}$ & Cleaned pellets & $\begin{array}{c}\text { Elem. removal }^{\mathbf{b}} \\
(\%)\end{array}$ & $\begin{array}{c}\text { Ca recovery } \\
(\%)\end{array}$ \\
\hline \multicolumn{5}{|l|}{ Emiliania huxleyi $^{d}$} \\
\hline $\mathbf{M g} / \mathrm{Ca}(\mathrm{mmol} / \mathrm{mol})$ & $48 \pm 4$ & $0.15 \pm 0.02$ & 99.69 & - \\
\hline $\mathrm{Sr} / \mathrm{Ca}(\mathrm{mmol} / \mathrm{mol})$ & $3.5 \pm 0.02$ & $2.73 \pm 0.22$ & 22.63 & - \\
\hline $\mathbf{P} / \mathbf{C a}(\mathrm{mmol} / \mathrm{mol})$ & $99 \pm 5$ & $0.75 \pm 0.24$ & 99.25 & - \\
\hline $\mathbf{F e} / \mathbf{C a}(\mathrm{mmol} / \mathrm{mol})$ & $392 \pm 31$ & $7.61 \pm 6.25$ & 98.06 & - \\
\hline $\mathbf{C a}(\mathrm{ppm})$ & $48 \pm 7$ & $18.9 \pm 0.66$ & - & 3.94 \\
\hline \multicolumn{5}{|l|}{ Calcidiscus leptoporus $^{d}$} \\
\hline $\mathbf{M g} / \mathrm{Ca}(\mathrm{mmol} / \mathrm{mol})$ & $4.2 \pm 0.4$ & $0.22 \pm 0.04$ & 94.79 & - \\
\hline $\mathrm{Sr} / \mathrm{Ca}(\mathrm{mmol} / \mathrm{mol})$ & $3.3 \pm 0.1$ & $3.05 \pm 0.01$ & 6.87 & - \\
\hline $\mathbf{P} / \mathbf{C a}(\mathrm{mmol} / \mathrm{mol})$ & $6 \pm 1$ & $0.40 \pm 0.31$ & 93.35 & - \\
\hline $\mathbf{F e} / \mathbf{C a}(\mathrm{mmol} / \mathrm{mol})$ & $27 \pm 3$ & $5.63 \pm 5.42$ & 79.62 & - \\
\hline $\mathbf{C a}(\mathrm{ppm})$ & $911 \pm 44$ & $162 \pm 14$ & - & 1.78 \\
\hline
\end{tabular}

(a) Elemental ratios obtained as a by-product in measurements of calcite (PIC) samples (from the same strain) where no cleaning procedure is applied. Measurements include elements in salt, organic, and carbonate phases. PIC data is shown in Table 1.

(b) The percentage of element removal during the cleaning process. Calculated as: [(non-treated samples - treated pellets $) \times 100] /$ non-treated samples.

(c) Ca concentration was not measured in the pellet previously to cleaning treatment. Therefore it was estimated based on the concentration measured in subsamples and the volume of culture used for the pellet production.

(d) Elemental ratios from PIC samples (non-treated) measured via ICP-AES are only available for these two strains and not for $G$. oceanica, where PIC was measured via Elemental Analyzer (see Table 1 for details)]. 
Fig.1: Schematic representation of two procedures to harvest coccolithophore pellets using different centrifugation devices: (a) Using a Hettich ROTANTA 460RS Centrifuge and flat-bottom

6 tubes allowing the manual pre-selection of $\mathrm{CaCO}_{3}$ in samples before applying cleaning protocols

7 and measuring in the ICP-AES. (b) Using a Beckman AVANTI ${ }^{\mathrm{TM}} \mathrm{J}-25$ Centrifuge and conical-

8 bottom tubes; the initial separation between calcite and organic matter is not obvious as in

9 procedure (a). Images taken by S. B. A. and M. L., and courtesy of the "Integration \& Application

10 Network" (http://ian.umces.edu/).

Fig.2: Elemental ratios measured in synthetic pellets with reagent grade $\mathrm{CaCO}_{3}$. Grey

13 circles $(\bullet)$ are synthetic pellets treated with different protocols applied to coccolithophore samples

14 from monoclonal cultures: A (Bleach oxidation), B (Bleach oxidation), C (Reductive incubation and

15 bleach oxidation), D ( $\mathrm{H}_{2} \mathrm{O}_{2}$ oxidation), $\mathrm{E}$ (Reductive incubation and $\mathrm{H}_{2} \mathrm{O}_{2}$ oxidation), $\mathrm{F}\left(\mathrm{H}_{2} \mathrm{O}_{2}\right.$

16 oxidation), $\mathrm{G}$ (Reductive incubation and $\mathrm{H}_{2} \mathrm{O}_{2}$ oxidation) and $\mathrm{H}$ (Reductive incubation and $\mathrm{H}_{2} \mathrm{O}_{2}$

17 oxidation). White diamonds $(\diamond)$ are the reagent grade $\mathrm{CaCO}_{3}$ measured in the same ICP-AES run.

18 (a) $\mathrm{Mg} / \mathrm{Ca}$ measured in reagent grade $\mathrm{CaCO}_{3}$ and the synthetic pellets treated following the different

19 protocols. (b) Sr/Ca. (c) Fe/ca. (d) P/Ca. Details about each protocol are given in Table 2 and raw

20 data of the measurements are given in EA-2.

Fig.3: $\mathrm{Mg} / \mathrm{Ca}$ of synthetic pellets treated with individual protocols plotted against the

23 corresponding $\mathrm{Fe} / \mathrm{Ca}(\mathrm{a}), \mathrm{P} / \mathrm{Ca}(\mathrm{b})$, used as indicators of organic phases contamination in biogenic

24 calcite, and calcium concentration (c). 
28 leptoporus cleaned with protocol H (UP + Red. + Oxid.). The relationship to the P/Ca is shown in

29 the $\mathrm{x}$-axis in (a) and (c), and to the $\mathrm{Fe} / \mathrm{Ca}$ in (b) and (d). We also determined the same ratios in

30 samples of treated and non-treated certified $\mathrm{CaCO}_{3}$ to remove organic $\mathrm{Mg}$ following protocol $\mathrm{H}$.

31 Bidirectional error bars (standard deviation) from repeated measurements of each pellet represent

32 the individual error of the analysis. In panel (b), the values indicate calcium concentration (ppm)

33 measured in each coccolithophore sample. $(*)$ Denotes average values.

Fig.5: Relationship of coccoliths $\mathrm{Mg} / \mathrm{Ca}$ and seawater $\mathrm{Mg} / \mathrm{Ca}$ in coccolithophores in this study and the literature. Coccolithophore data from the literature were selected including samples grown at $\sim 20^{\circ} \mathrm{C}$. Average North Atlantic Ocean seawater $\mathrm{Mg} / \mathrm{Ca}$ used for the data set from Stoll et al., 2007 were taken from Fabricand et al., 1967. Bidirectional error bars represent the standard deviation from repeated measurements of each sample. Solid line represents the regression plot which linear equation is: $y=0.2894 \pm 0.0012 x-1.4851 \pm 0.0009 ; \mathrm{R}^{2}=0.838 ; \mathrm{F}=140.398$ and $\mathrm{P}<$ 


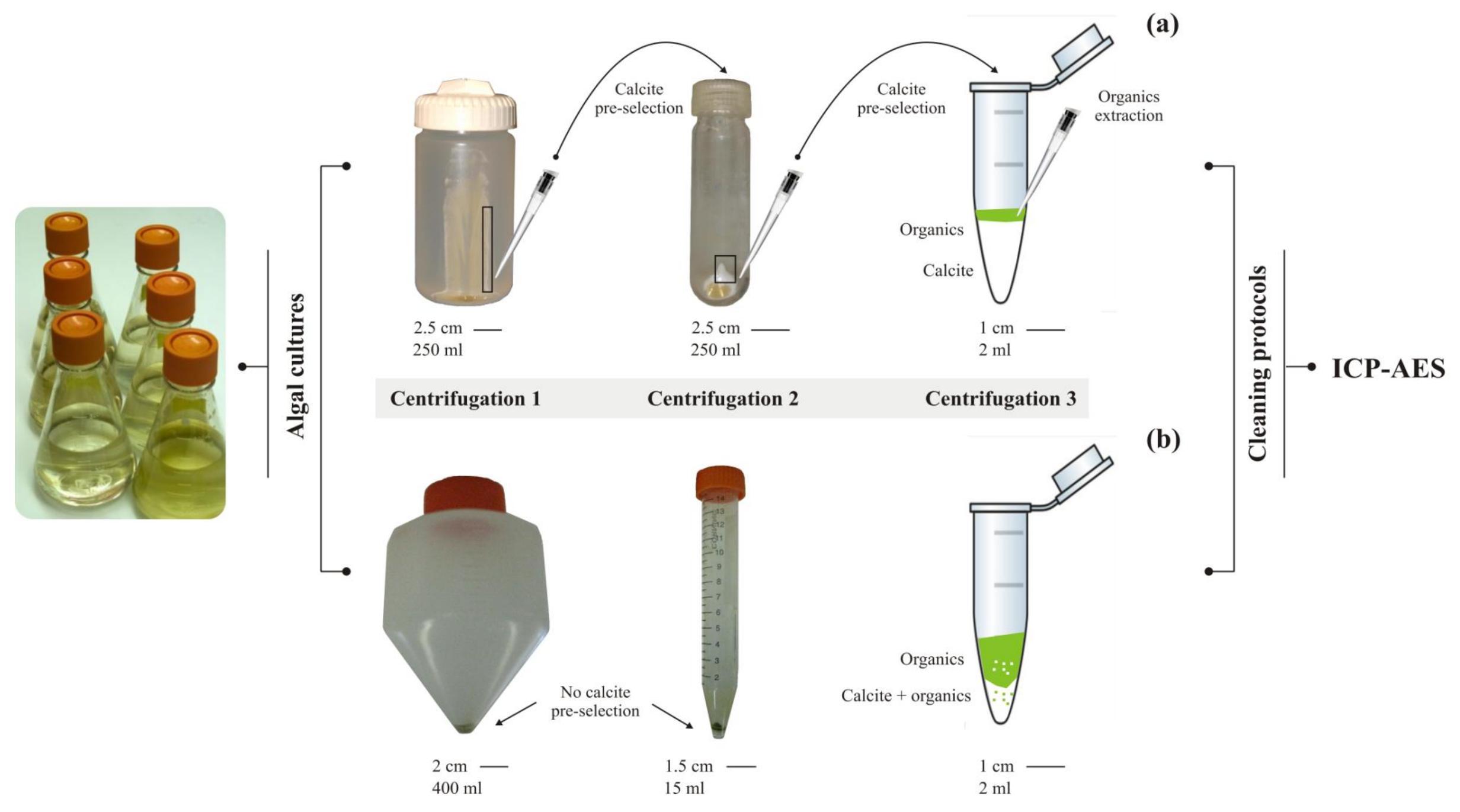



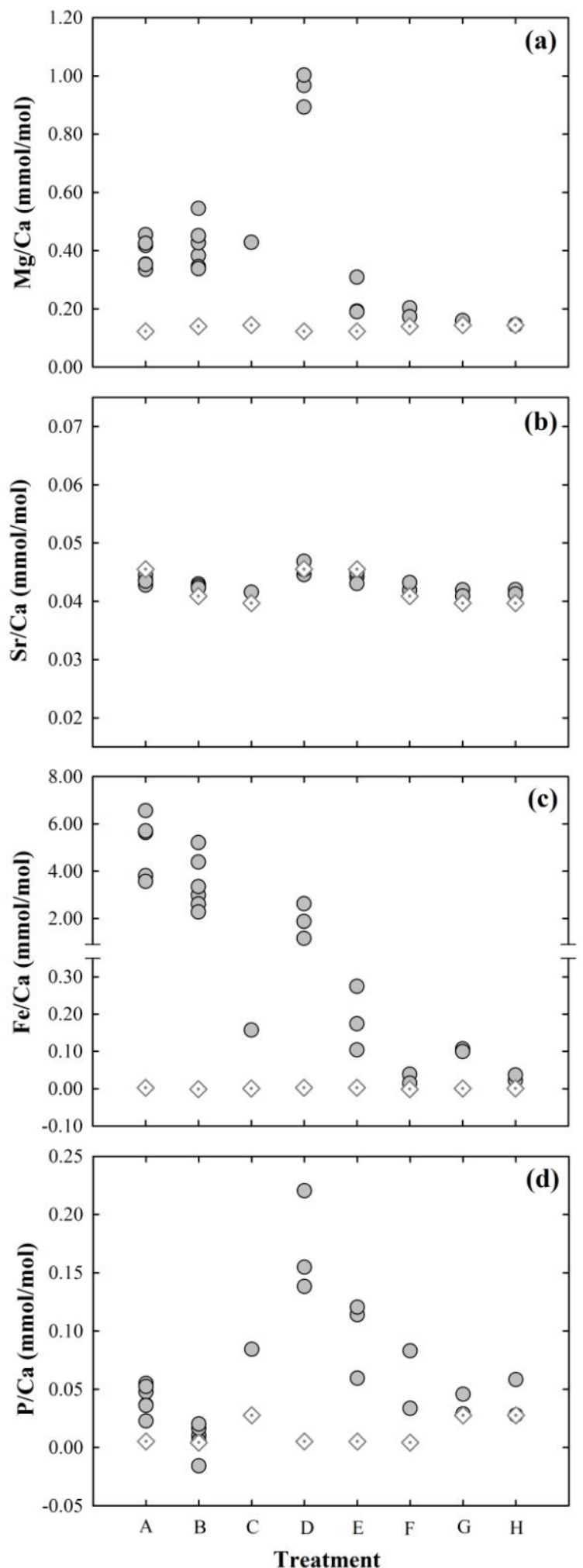

59 Fig. 2 

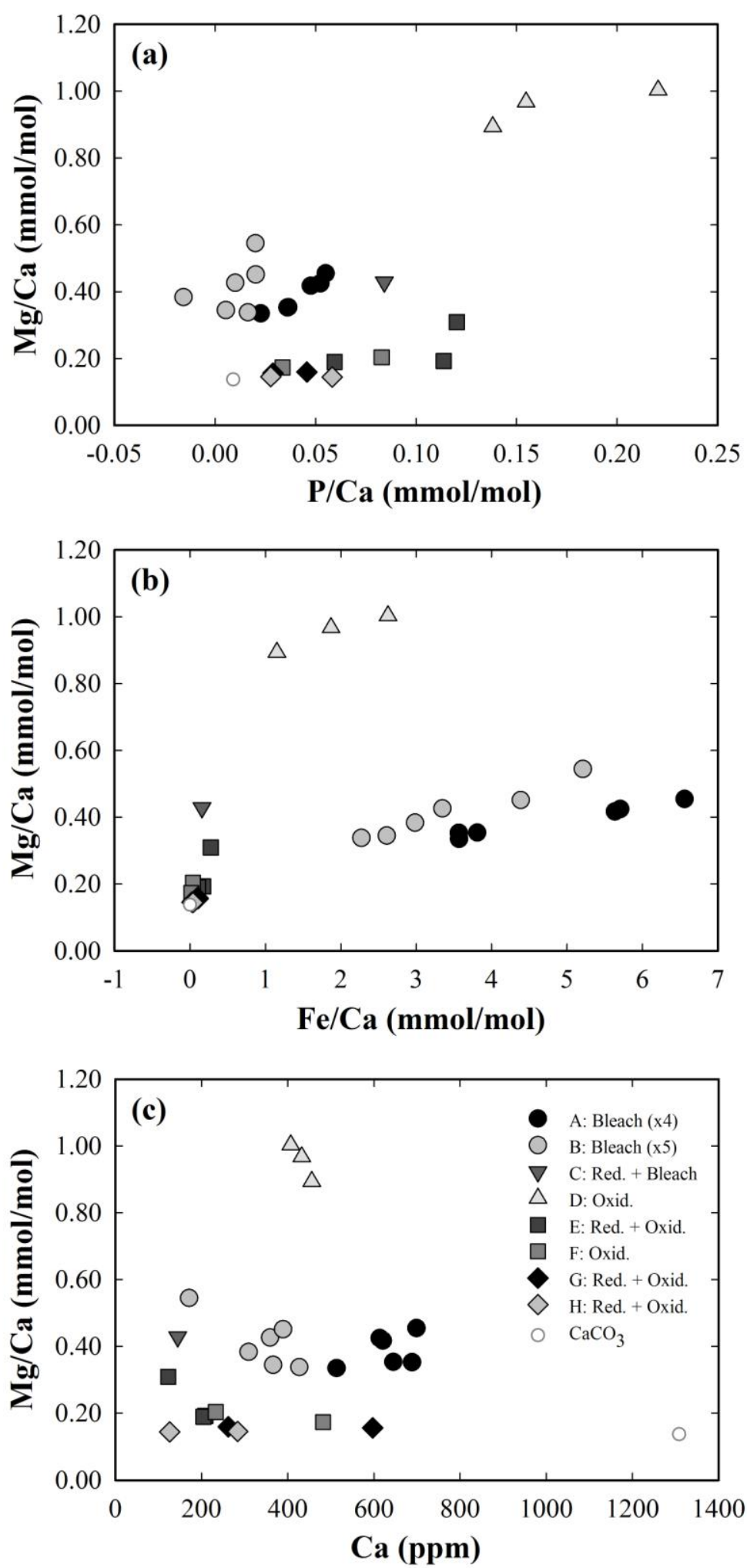

63 Fig. 3 


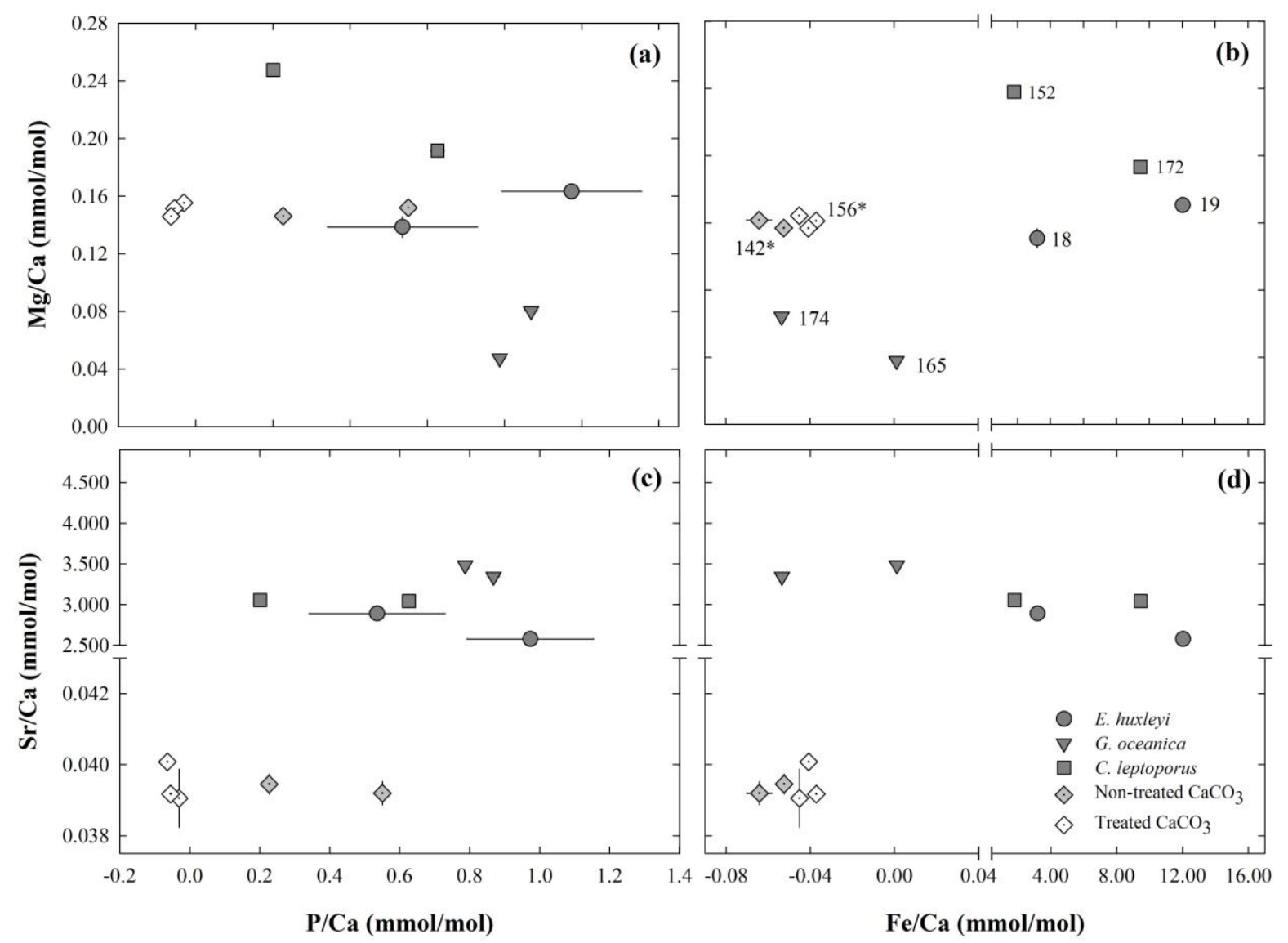

66

67 Fig. 4

68

69

70

71

72

73

74

75

76 


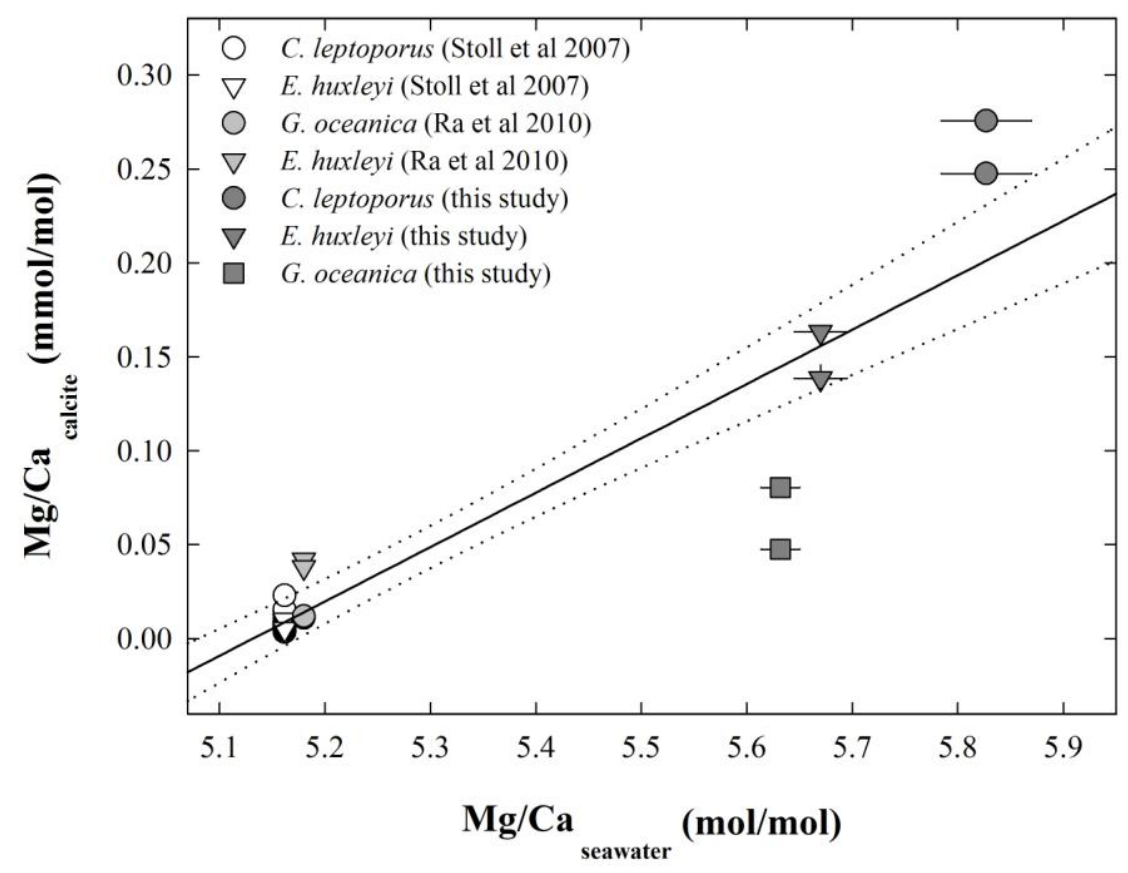

80

81 Fig. 5 


\section{ELECTRONIC ANNEXES}

EA-1. Characterization of the synthetic pellets produced by mixing the non-calcifying alga

Chlorella autotrophica + reagent-grade $\mathrm{CaCO}_{3}$, and the treatments for what they ave been used.

\begin{tabular}{|c|c|c|c|c|c|c|}
\hline Pellet $\mathrm{n}^{\circ}$ a & Label $^{b}$ & $\begin{array}{l}\text { Cell density } \\
\left(\text { cell } \mathrm{ml}^{-1}\right)\end{array}$ & $\begin{array}{l}\text { Total cells } \\
\text { (in } 50 \mathrm{ml} \text { ) }\end{array}$ & $\begin{array}{l}\text { Pellet weight } \\
(\mathrm{mg}) \mathrm{d}\end{array}$ & $\begin{array}{c}\mathrm{CaCO}_{3} / \text { organic }_{(w t / w t}{ }^{e} \\
{ }_{(w 1 / c}\end{array}$ & Protocol key \\
\hline 1 & $\mathrm{a}$ & $1.93 \times 10^{6}$ & $2.316 \times 10^{9}$ & 64.50 & 0.775 & A-B \\
\hline 2 & $\mathrm{a}$ & $1.93 \times 10^{6}$ & $2.316 \times 10^{9}$ & 64.20 & 0.778 & A - B \\
\hline 3 & $\mathrm{~b}$ & $1.66 \times 10^{6}$ & $1.992 \times 10^{9}$ & 65.50 & 0.763 & $A-B$ \\
\hline 4 & $\mathrm{~b}$ & $1.66 \times 10^{6}$ & $1.992 \times 10^{9}$ & 68.30 & 0.732 & $A-B$ \\
\hline 5 & $\mathrm{c}$ & $9.45 \times 10^{5}$ & $1.134 \times 10^{9}$ & 62.40 & 0.801 & $A-B$ \\
\hline 6 & $\mathrm{c}$ & $9.45 \times 10^{5}$ & $1.134 \times 10^{9}$ & 62.00 & 0.806 & $A-B$ \\
\hline 7 & $\mathrm{a}$ & $1.93 \times 10^{6}$ & $2.316 \times 10^{9}$ & 64.60 & 0.773 & $\mathrm{C}$ \\
\hline 8 & $\mathrm{a}$ & $1.93 \times 10^{6}$ & $2.316 \times 10^{9}$ & 65.30 & 0.765 & $\mathrm{C}$ \\
\hline 9 & $\mathrm{a}$ & $1.93 \times 10^{6}$ & $2.316 \times 10^{9}$ & 70.40 & 0.710 & D \\
\hline 10 & $\mathrm{~b}$ & $1.66 \times 10^{6}$ & $1.992 \times 10^{9}$ & 64.70 & 0.772 & D \\
\hline 11 & $\mathrm{c}$ & $9.45 \times 10^{5}$ & $1.134 \times 10^{9}$ & 61.00 & 0.819 & $\mathrm{D}$ \\
\hline 12 & $\mathrm{a}$ & $1.93 \times 10^{6}$ & $2.316 \times 10^{9}$ & 65.20 & 0.778 & $E-F$ \\
\hline 13 & $\mathrm{~b}$ & $1.66 \times 10^{6}$ & $1.992 \times 10^{9}$ & 64.70 & 0.772 & E - F \\
\hline 14 & $\mathrm{c}$ & $9.45 \times 10^{5}$ & $1.134 \times 10^{9}$ & 62.40 & 0.801 & $E-F$ \\
\hline 15 & $\mathrm{~b}$ & $1.66 \times 10^{6}$ & $1.992 \times 10^{9}$ & 64.50 & 0.775 & G \\
\hline 16 & $\mathrm{~b}$ & $1.66 \times 10^{6}$ & $1.992 \times 10^{9}$ & 65.50 & 0.763 & $\mathrm{H}$ \\
\hline 17 & g g & 0 & 0 & 192.90 & Pure calcite ${ }^{h}$ & - \\
\hline 18 & - & 0 & 0 & 197.30 & Pure calcite $\mathrm{h}^{\mathrm{h}}$ & - \\
\hline
\end{tabular}

(a) Pellet code given for identification purposes for the different protocols.

(b) The label indicates the origin of the seawater batch with a different cell density for a, b, and c. Chlorella autotrophica were grown in each batch (12 L).

(c) Cell density in $50 \mathrm{ml}$ aliquots. $5 \mathrm{ml}$ were transferred from the re-suspended material to the final pellets.

(d) Dry weight only from the organic material.

(e) The $\mathrm{CaCO}_{3}$ dry weight is $50 \mathrm{mg}$ for all treatments. The ratio (by weight) varies depending on the amount of organic pellet centrifuged. It resembles the proportions found in pellets made from living E. huxleyi cells with a high calcite content.

(f) The code is used to identify the protocols applied to each pellet in Table 2 .

(g) - indicates "not applicable" or "not given" in all tables.

(h) Only calcite re-suspended and centrifuged in the treatments. 
EA-2. Carbonate $\mathrm{P} / \mathrm{Ca}$ and $\mathrm{Fe} / \mathrm{Ca}$ (contamination proxies), $\mathrm{Mg} / \mathrm{Ca}, \mathrm{Sr} / \mathrm{Ca}, \mathrm{Ca}$ concentration and percentage of sample recovery determined in the synthetic pellets (Chlorella autotrophica + $\mathrm{CaCO}_{3}$ ) pellets treated with different protocols and the reference $\mathrm{CaCO}_{3}$ material used.

\begin{tabular}{|c|c|c|c|c|c|c|c|c|}
\hline Protocol key & $\mathbf{A}$ & B & $\mathbf{C}$ & D & $\mathbf{E}$ & $\mathbf{F}$ & G & $\mathbf{H}$ \\
\hline $\begin{array}{l}\text { Cleaning protocol } \\
\text { Pellet } \mathbf{n}^{\mathbf{0}}\end{array}$ & $\begin{array}{l}\text { Bleach } \\
(1-6)\end{array}$ & $\begin{array}{l}\text { Bleach } \\
(1-6)\end{array}$ & $\begin{array}{l}\text { Red. } \\
\text { Bleach } \\
\quad(8)\end{array}$ & Oxid. & $\begin{array}{l}\text { Red. } \\
\text { Oxid. } \\
(12-14)\end{array}$ & Oxid. & $\begin{array}{l}\text { Red. } \\
\text { Oxid. } \\
(15)\end{array}$ & $\begin{array}{r}\text { Red. } \\
\text { Oxid. } \\
(16)\end{array}$ \\
\hline \multirow[t]{6}{*}{ P/Ca (mmol/mol) } & 0.037 & 0.016 & - & - & - & - & - & - \\
\hline & 0.048 & 0.01 & - & - & - & - & - & - \\
\hline & 0.023 & 0.005 & - & - & - & - & - & - \\
\hline & 0.036 & 0.016 & - & 0.138 & 0.114 & - & - & - \\
\hline & 0.055 & 0.02 & - & 0.155 & 0.12 & 0.083 & 0.029 & 0.028 \\
\hline & 0.052 & 0.02 & 0.084 & 0.22 & 0.059 & 0.034 & 0.046 & 0.058 \\
\hline Average & 0.042 & 0.009 & 0.084 & 0.171 & 0.098 & 0.058 & 0.037 & 0.043 \\
\hline$S D$ & 0.012 & 0.014 & 0 & 0.043 & 0.033 & 0.035 & 0.012 & 0.022 \\
\hline Reagent $\mathrm{CaCO}_{3}$ & 0.005 & 0.004 & 0.028 & 0.005 & 0.005 & 0.004 & 0.028 & 0.028 \\
\hline $\mathrm{SD}$ & 0.001 & 0.004 & 0.008 & 0.001 & 0.001 & 0.004 & 0.008 & 0.008 \\
\hline \multirow[t]{6}{*}{$\mathrm{Fe} / \mathrm{Ca}(\mathrm{mmol} / \mathrm{mol})$} & 3.811 & 2.987 & - & - & - & - & - & - \\
\hline & 5.636 & 3.349 & - & - & - & - & - & - \\
\hline & 3.568 & 2.609 & - & - & - & - & - & - \\
\hline & 3.566 & 2.272 & - & 1.150 & 0.174 & - & - & - \\
\hline & 6.559 & 4.388 & - & 1.867 & 0.275 & 0.039 & 0.107 & 0.022 \\
\hline & 5.707 & 5.209 & 0.157 & 2.626 & 0.104 & 0.015 & 0.099 & 0.037 \\
\hline Average & 4.808 & 3.469 & 0.157 & 1.881 & 0.184 & 0.027 & 0.103 & 0.029 \\
\hline$S D$ & 1.314 & 1.122 & 0 & 0.738 & 0.086 & 0.017 & 0.005 & 0.01 \\
\hline Reagent $\mathrm{CaCO}_{3}$ & 0.003 & 0 & 0.001 & 0.003 & 0.003 & 0 & 0.001 & 0.001 \\
\hline SD & 0.002 & 0.001 & 0.001 & 0.002 & 0.002 & 0.001 & 0.001 & 0.001 \\
\hline \multirow[t]{6}{*}{ Mg/Ca (mmol/mol) } & 0.354 & 0.383 & - & - & - & - & - & - \\
\hline & 0.417 & 0.427 & - & - & - & - & - & - \\
\hline & 0.335 & 0.345 & - & - & - & - & - & - \\
\hline & 0.353 & 0.338 & - & 0.893 & 0.193 & - & - & - \\
\hline & 0.455 & 0.452 & - & 0.967 & 0.309 & 0.204 & 0.156 & 0.145 \\
\hline & 0.425 & 0.545 & 0.429 & 1.003 & 0.190 & 0.173 & 0.16 & 0.144 \\
\hline Average & 0.39 & 0.415 & 0.429 & 0.954 & 0.230 & 0.188 & 0.158 & 0.144 \\
\hline$S D$ & 0.049 & 0.078 & 0 & 0.056 & 0.068 & 0.021 & 0.003 & 0.001 \\
\hline Reagent $\mathrm{CaCO}_{3}$ & 0.123 & 0.14 & 0.144 & 0.123 & 0.123 & 0.14 & 0.144 & 0.144 \\
\hline $\mathrm{SD}$ & 0.007 & 0.001 & 0 & 0.007 & 0.007 & 0.001 & 0 & 0 \\
\hline \multirow[t]{6}{*}{$\mathrm{Sr} / \mathrm{Ca}(\mathrm{mmol} / \mathrm{mol})$} & 0.044 & 0.043 & - & - & - & - & - & - \\
\hline & 0.044 & 0.043 & - & - & - & - & - & - \\
\hline & 0.043 & 0.043 & - & - & - & - & - & - \\
\hline & 0.044 & 0.043 & - & 0.045 & 0.044 & - & - & - \\
\hline & 0.045 & 0.043 & - & 0.045 & 0.045 & 0.042 & 0.042 & 0.042 \\
\hline & 0.043 & 0.042 & 0.042 & 0.047 & 0.043 & 0.043 & 0.041 & 0.041 \\
\hline Average & 0.044 & 0.043 & 0.042 & 0.046 & 0.044 & 0.043 & 0.041 & 0.042 \\
\hline$S D$ & 0.001 & 0 & 0 & 0.001 & 0.001 & 0.001 & 0.001 & 0.001 \\
\hline Reagent $\mathrm{CaCO}_{3}$ & 0.046 & 0.041 & 0.04 & 0.046 & 0.046 & 0.041 & 0.04 & 0.04 \\
\hline $\mathrm{SD}$ & 0.001 & 0.003 & 0 & 0.001 & 0.001 & 0.003 & 0 & 0 \\
\hline \multirow[t]{5}{*}{ Ca (ppm) } & 645.3 & 309.1 & - & - & - & - & - & - \\
\hline & 621.0 & 358.8 & - & - & - & - & - & - \\
\hline & 512.9 & 365.9 & - & - & - & - & - & - \\
\hline & 688.7 & 426.7 & - & 455.6 & 208.8 & - & - & - \\
\hline & 698.8 & 388.7 & - & 432.1 & 122.5 & 232.5 & 597.1 & 283.3 \\
\hline
\end{tabular}




$\begin{array}{lcccccccc} & 613.7 & 170.9 & 144.7 & 406.6 & 204.3 & 481.6 & 262.2 & 125.6 \\ \text { Average } & \mathbf{6 3 0 . 1} & \mathbf{3 3 6 . 7} & \mathbf{1 4 4 . 7} & \mathbf{4 3 1 . 5} & \mathbf{1 7 8 . 5} & \mathbf{3 5 7 . 1} & \mathbf{4 2 9 . 6} & \mathbf{2 0 4 . 4} \\ \text { SD } & 67.0 & 89.9 & 0.0 & 24.5 & 48.5 & 176.2 & 236.8 & 111.5 \\ \text { Reagent } \mathrm{CaCO} 3 & \mathbf{2 8 4 9 . 3} & \mathbf{6 3 5 . 4} & 215.7 & \mathbf{2 8 4 9 . 3} & \mathbf{2 8 4 9 . 3} & \mathbf{6 3 5 . 4} & \mathbf{2 1 5 . 7} & \mathbf{2 1 5 . 7} \\ \mathrm{SD} & 756.5 & 72.7 & 89.6 & 756.5 & 756.5 & 72.7 & 89.6 & 89.6\end{array}$

\section{Sample recovery}

(\%)

(

Average

$S D$

Reagent $\mathrm{CaCO}_{3}$

$\mathrm{SD}$

$\begin{array}{llr}0.21 & 0.10 & - \\ 0.20 & 0.11 & - \\ 0.17 & 0.12 & - \\ 0.23 & 0.15 & - \\ 0.22 & 0.12 & - \\ 0.19 & 0.05 & 0.05 \\ \mathbf{0 . 2 0} & \mathbf{0 . 1 1} & \mathbf{0 . 0} \\ 0.02 & 0.03 & 0.00 \\ 2.75 & \mathbf{0 . 5 7} & \mathbf{0 . 1} \\ 0.73 & 0.07 & 0.0\end{array}$

0.16

$0.14 \quad 0.04$

$0.12 \quad 0.06$

$0.14 \quad 0.06$

$0.02 \quad 0.02$

$\begin{array}{ll}2.75 & 2.75\end{array}$

$\begin{array}{ll}0.73 & 0.73\end{array}$

$\begin{array}{ccc}- & - & - \\ - & - & - \\ - & - & - \\ - & - & - \\ 0.08 & 0.19 & 0.09 \\ 0.15 & 0.08 & 0.04 \\ \mathbf{0 . 1 1} & \mathbf{0 . 1 4} & \mathbf{0 . 0 7} \\ 0.05 & 0.08 & 0.04 \\ \mathbf{0 . 5 7} & \mathbf{0 . 1 8} & \mathbf{0 . 1 8} \\ 0.07 & 0.07 & 0.07\end{array}$

(a) Values of reference $\mathrm{CaCO}_{3}$ powder sample used changed according to protocol used (also in different dates). 